\title{
PENGARUH JOB SATISFACTION DAN PAY SATISFACTION TERHADAP TURNOVER INTENTION KARYAWAN DENGAN KOMITMEN ORGANISASIONAL SEBAGAI VARIABEL INTERVENING
}

Aris Susetyo, SE, MM, Ak

\begin{abstract}
Abstraksi
Tingkat turnover yang tinggi akan menimbulkan dampak negatif bagi organisasi, hal ini seperti menciptakan ketidakstabilan dan ketidakpastian (uncertainity) terhadap kondisi tenaga kerja dan peningkatan biaya sumber daya manusia yakni yang berupa biaya pelatihan yang sudah diinvestasikan pada karyawan sampai biaya rekrutmen dan pelatihan kembali. Turnover yang tinggi juga mengakibatkan organisasi tidak efektif karena perusahaan kehilangan karyawan yang berpengalaman dan perlu melatih kembali karyawan baru.

Tujuan dilakukannya penelitian ini adalah untuk menguji pengaruh job satisfaction dan pay satisfaction terhadap turnover intention karyawan dengan komitmen organisasional sebagai variabel intervening di Bale Group Kebumen. Metode pengambilan sampel yang digunakan adalah sampling jenuh/sensus yaitu teknik penentuan sampel bila semua anggota populasi digunakan sebagai sampel. Pemilihan metode sampling jenuh/sensus dilakukan karena semua populasi dinilai memiliki kriteria tertentu untuk diteliti.

Responden pada penelitian ini adalah karyawan tetap Bale Group Kebumen yang berjumlah 102 responden. Penelitian ini mengggunakan metode analisis deskriptif dan statistika dengan bantuan program Amos 21 dan SPSS 22. Dalam metode statistika dilakukan uji validitas, reliabilitas, uji normalitas, outliers, multikolineritas dan singularitas, uji kesalahan spesifikasi model, analisis faktor konfirmatori dan analisis Structural Equation Modeling (SEM).

Pengujian hipotesis dalam uji regression weight menunjukkan bahwa job satisfaction berpengaruh dan signifikan terhadap komitmen organisasional dengan nilai CR sebesar 2,110 dan probabilitas sebesar 0,035. Pay satisfaction berpengaruh dan signifikan terhadap komitmen organisasional dengan nilai CR sebesar -2,056 dan probabilitas sebesar 0,040. Job satisfaction berpengaruh dan signifikan terhadap turnover intention dengan nilai CR sebesar 2,097 dan probabilitas sebesar 0,036. Pay satisfaction berpengaruh dan signifikan terhadap turnover intention dengan nilai CR sebesar 2,984 dan probabilitas sebesar 0,003. Komitmen organisasional tidak berpengaruh dan tidak signifikan terhadap turnover intention dengan nilai CR sebesar 1,103 dan probabilitas sebesar 0,270.
\end{abstract}

Kata Kunci : job satisfaction, pay satisfaction, komitmen organisasional, turnover intentions, SEM (Structural Equation Modeling).

\section{PENDAHULUAN}

Bagi suatu organisasi, kinerja karyawan sangatlah penting karena kinerja menunjukan bagaimana karyawan melakukan segala sesuatu yang berhubungan dengan pekerjaannya. Dalam organisasi, kinerja suatu perusahaan sangat ditentukan oleh kondisi dan perilaku karyawan yang dimiliki perusahaan tersebut. Fenomena yang seringkali terjadi adalah kinerja yang telah demikian bagus dapat dirusak, baik secara langsung maupun tidak oleh berbagai perilaku karyawan. Salah satu bentuk perilaku karyawan tersebut adalah niat untuk pindah kerja (turnover intention) yang berujung pada keputusan karyawan untuk meninggalkan pekerjaannya. 
Tingginya tingkat turnover karyawan akan menimbulkan dampak negatif bagi organisasi seperti menciptakan ketidakstabilan kondisi tenaga kerja untuk memberikan kualitas pelayanan pada perusahaan. Pada umumnya perusahaan selalu berusaha untuk mengurangi tingkat turnover yang terjadi pada karyawannya, karena akan mengakibatkan timbulnya kerugian yang cukup material pada perusahaan. Selain berdampak negatif pada ketidakstabilan kondisi tenaga kerja, tingginya tingkat turnover juga dapat meningkatkan biaya sumber daya manusia, baik itu biaya pelatihan yang sudah diinvestasikan pada karyawan, biaya kompensasi atau tunjangan, maupun biaya rekrutmen dan pelatihan kembali (Suwandi dan Indriantoro, 1999). Hal ini dapat menjadikan organisasi tidak efektif karena perusahaan dapat kehilangan karyawan yang berpengalaman dan akan memerlukan waktu untuk dapat melatih karyawan baru.

Dalam beberapa kasus tertentu, turnover memang diperlukan oleh perusahaan terutama terhadap karyawan dengan kinerja rendah, namun tingkat turnover tersebut harus diupayakan agar tidak terlalu tinggi sehingga perusahaan masih memiliki kesempatan untuk memperoleh manfaat atau keuntungan atas peningkatan kinerja dari karyawan baru yang lebih besar dibanding biaya rekrutmen yang ditanggung perusahaan.

Turnover intention harus disikapi sebagai suatu fenomena dan perilaku manusia yang penting dalam kehidupan perusahaan dari sudut pandang individu maupun sosial, mengingat bahwa tingkat keinginan berpindah karyawan tersebut akan mempunyai dampak yang cukup signifikan bagi perusahaan dan individu yang bersangkutan.

Saat ini tingginya tingkat turnover intention telah menjadi masalah yang serius bagi banyak perusahaan, bahkan beberapa Manajer Personalia mengalami frustasi ketika mengetahui bahwa proses rekrutmen yang telah berhasil menjaring staf yang dapat dipercaya dan berkualitas pada akhirnya siasia karena staf yang baru direkrut tersebut telah memilih pekerjaan di perusahaan lain (Toly, 2001).

Turnover intention atau niat untuk pindah didefinisikan sebagai penarikan diri secara sukarela (voluntary) atau tidak sukarela (involuntary) dari suatu organisasi (Robbins, 1996). Dalam penelitian ini, turnover intention karyawan lebih difokuskan pada voluntary turnover yaitu yang terjadi secara sukarela berdasarkan keinginan dari dalam diri karyawan itu sendiri. Turnover intention yang terjadi atas keinginan dari dalam diri karyawan itu sendiri terhadap organisasi, biasanya disebabkan karena karyawan memiliki komitmen organisasional, kepuasan kerja dan kepuasan gaji yang rendah atas pekerjaannya yang ada sekarang dan termotivasi untuk mencari pekerjaan lain. Turnover intention akibat dari keinginan dari dalam diri karyawan itu sendiri, merupakan hal yang sangat penting untuk dihindari perusahaan agar tidak menimbulkan kerugian yang tidak diinginkan sehingga perlu diusahakan pengendaliannya.

Komitmen organisasional adalah tingkatan dimana seorang pekerja mengidentifikasikan diri dengan organisasi dan tujuan-tujuannya dan berkeinginan untuk memelihara keanggotaannya dalam organisasi (Robbins, 2001). Karyawan dengan komitmen yang tinggi tetap tinggal dengan organisasi karena mereka mengenal organisasi dan terikat untuk tetap menjadi anggota organisasi untuk mencapai tujuan organisasi. Mereka yang memiliki komitmen yang tinggi tetap tinggal dalam organisasi karena mereka butuh uang pensiun, fasilitas, dan senioritas atau mereka harus membayar biaya karena pindah kerja, bukan karena adanya hubungan yang menyenangkan dengan organisasi. Disamping itu karyawan yang memiliki komitmen yang tinggi tetap tinggal karena mereka menginginkannya.

Adapun karyawan yang mempunyai komitmen terhadap organisasi disebabkan karena organisasi mempunyai komitmen terhadap karyawan yang bersangkutan. Apabila organisasi tidak mempunyai komitmen terhadap karyawan yang bersangkutan, maka dimungkinkan karyawan 
tersebut mempunyai keinginan pindah dari tempatnya bekerja sekarang.

Kepuasan gaji dapat diartikan bahwa seseorang akan terpuaskan dengan gajinya ketika persepsi terhadap gaji dan apa yang mereka peroleh sesuai dengan yang diharapkan (Lum et al, 1999). Ketika seorang karyawan merasakan adanya rasa keadilan (equity) terhadap gaji yang diterima sehubungan dengan pekerjaan yang dilakukannya, maka karyawan tersebut akan tetap bertahan dalam organisasi. Sedangkan karyawan yang merasa kurang terpuaskan dengan gajinya cenderung akan memilih untuk keluar dari organisasi.

Kepuasan kerja merupakan sikap umum individu terhadap pekerjaannya atau penilaian karyawan atas seberapa puas atau tidak puas dirinya dengan pekerjaannya (Robbins, 2001). Seorang karyawan akan merasa puas atas kerja yang telah atau sedang dilakukan, apabila apa yang dikerjakan itu dianggapnya telah memenuhi harapannya, sesuai dengan tujuan dia bekerja. Apabila seseorang mendambakan sesuatu, maka itu berarti dia memiliki suatu harapan dan dengan demikian dia akan termotivasi untuk melakukan tindakan kearah pencapaian harapan tersebut. Jika harapannya terpenuhi, maka dia akan merasa puas. Tetapi, jika harapannya tidak terpenuhi, maka dia tidak akan merasa puas, sehingga perasaan karyawan untuk pindah dari pekerjaannya sekarang semakin besar.

Bale Group Kebumen adalah salah satu organisasi bisnis yang bergerak dibidang kuliner. Selain menyediakan aneka ragam masakan, di kafe milik Bale Group Kebumen juga menyediakan fasilitas ruang meeting dan karaoke bagi pengunjung. Dalam menyelenggarakan pelayanan terhadap konsumen, Bale Group Kebumen dituntut untuk bisa memberikan layanan yang terbaik, peka terhadap perubahan yang terjadi di lingkungan, memiliki kemampuan manajemen yang baik dan mampu mencari terobosan untuk mengatasi segala kendala yang terjadi.

Kurangnya komitmen organisasional yang dimiliki oleh karyawan Bale Group Kebumen biasanya disebabkan oleh ketidakmampuan karyawan dalam mengidentifikasi semua permasalahan yang ada di tempat kerja, karyawan tidak dilibatkan dalam setiap kegiatan yang dilaksanakan oleh tempat kerja dan karyawan tidak loyal terhadap instansi tempatnya bekerja. Hal ini menyebabkan terjadinya kecemburuan sosial antar karyawan. Sehingga semakin hari produktivitas karyawan dirasa menurun. kurangnya komitmen juga bisa berujung pada turnover intention karyawan yang meningkat.

Rendahnya kepuasan gaji karyawan Bale Group Kebumen ditandai dengan adanya karyawan yang merasa penghasilan yang didapatkan belum mampu memenuhi kebutuhan hidup sehari-hari, imbalan yang diterima karyawan belum sebanding dengan pekerjaan yang dihasilkan oleh karyawan, organisasi atau perusahaan tidak melakukan penyesuaian gaji terhadap kebutuhan karyawan dan gaji yang diterima karyawan tidak sesuai dengan peraturan sistem penggajian antara usaha/kerja dan pelaksanaannya oleh bagian keuangan. Ketika hal ini terjadi, maka karyawan akan cenderung berniat untuk pindah kerja sehingga dapat merugikan perusahaan.

Rendahnya kepuasan kerja karyawan Bale Group Kebumen disebabkan oleh rasa ketidakpuasan karyawan dengan tingkat kemajuan yang didapatkannya, sebagian besar karyawan merasa atasan kurang mendukung terhadap pekerjaan yang telah mereka lakukan, ada juga karyawan yang merasa kurang berhasil dalam melakukan pekerjaannya, karyawan merasa jarang terjadi sistem promosi yang diberikan dan ketika seorang karyawan meminta rekan kerjanya untuk melakukan pekerjaan tertentu, pekerjaan yang dilakukan dirasa kurang menarik sehingga suasana kerja menjadi tidak kondusif, Dengan demikian, karyawan merasa cemas, tidak bersemangat, tidak bisa menikmati pekerjaan dan tidak betah dengan pekerjaan sekarang. Maka hal tersebut tidak bisa dibiarkan karena bisa mengganggu kinerja organisasi secara keseluruhan. Ketika hal ini terjadi, maka akan timbul penurunan rasa puas terhadap pekerjaan sehingga kondisi 
seperti ini akan mengakibatkan karyawan berniat untuk pindah kerja.

\section{Permasalahan}

Berdasarkan latar belakang permasalahan di atas, maka rumusan masalah dalam penelitian ini adalah bagaimanakah pengaruh job satisfaction (kepuasan kerja) dan pay satisfaction (kepuasan gaji) terhadap turnover intention (niat untuk pindah kerja) karyawan dengan komitmen organisasional sebagai variabel intervening di Bale Group Kebumen.

\section{Batasan Masalah}

Berdasarkan latar belakang di atas, masalah batasan masalah dalam penelitian ini adalah sebagai berikut:

1. Penelitian ini difokuskan hanya pada faktor pengaruh job satisfaction (kepuasan kerja), pay satisfaction (kepuasan gaji) dan komitmen organisasional sebagai variabel intervening yang dapat mempengaruhi turnover intention karyawan Bale Group Kebumen.

2. Data yang akan diperoleh berasal dari kuesioner karyawan tetap Bale Group Kebumen.

3. Variabel Turnover intention dalam penelitian ini menggunakan variabel penelitian yang dilakukan oleh Lee dan Mowday (1987) :

a. Pikiran untuk keluar dari organisasi.

b. Kemungkinan untuk mencari pekerjaan baru.

c. Keaktifan dalam mencari pekerjaan baru.

4. Variabel komitmen organisasional dalam penelitian ini menggunakan variabel penelitian yang dilakukan oleh Steers (1988) :
a. Identification (Identifikasi).
b. Involvement (Keterlibatan).
c. Loyality (Loyalitas).

5. Variabel Pay satisfaction dalam penelitian ini menggunakan variabel penelitian yang dilakukan oleh Adams (1965) :
a. Economic need.
b. Ekuitas.
c. Organizational support.

6. Variabel Job satisfaction atau kepuasan kerja dalam penelitian ini menggunakan variabel penelitian yang dilakukan oleh Luthans (2006) :
a. Gaji.
b. Kesempatan promosi.
c. Rekan kerja.
d. Pengawasan.
e. Pekerjaan itu sendiri.

\section{Tujuan Penelitian}

Berdasarkan masalah penelitian dan pertanyaan penelitian yang telah dirumuskan, maka tujuan dari penelitian ini adalah untuk:

1. Menganalisis pengaruh job satisfaction terhadap komitmen organisasional.

2. Menganalisis pengaruh pay satisfaction terhadap komitmen organisasional.

3. Menganalisis pengaruh job satisfaction terhadap turnover intention.

4. Menganalisis pengaruh pay satisfaction terhadap turnover intention.

5. Menganalisis pengaruh komitmen organisasional terhadap turnover intention.

\section{LANDASAN TEORI \\ Definisi Turnover Intention}

Menurut Zeffane (1994) intensi adalah niat atau keinginan yang timbul pada individu untuk melakukan sesuatu. Sementara turnover adalah berhentinya atau penarikan diri seseorang karyawan dari tempat bekerja. Dengan demikian, turnover intention (intensi keluar) adalah kecenderungan atau niat karyawan untuk berhenti bekerja dari pekerjaannya.

Intensi keluar (turnover intension) juga dapat diartikan sebagai pergerakan tenaga kerja keluar dari organisasi. Turnover mengarah pada kenyataan akhir yang dihadapi organisasi berupa jumlah karyawan yang meninggalkan organisasi pada periode tertentu, sedangkan keinginan karyawan untuk berpindah mengacu pada hasil evaluasi individu mengenai kelanjutan hubungan dengan organisasi yang belum diwujudkan dalam tindakan pasti meninggalkan organisasi. Turnover dapat berupa pengunduran diri, perpindahan keluar unit 
organisasi, pemberhentian atau kematian anggota organisasi.

Menurut Lum et.al., (1999) mengemukakan bahwa keinginan untuk keluar dari organisasi yaitu evaluasi, mengenai posisi seseorang saat ini berkenaan dengan ketidakpuasan yang memicu keinginan seseorang untuk keluar dan mencari pekerjaan lain.

Menurut Robbins (1996) turnover intention atau niat untuk pindah didefinisikan sebagai penarikan diri secara sukarela (voluntary) atau tidak sukarela (involuntary) dari suatu organisasi. Voluntary turnover atau quit merupakan keputusan untuk meninggalkan organisasi, disebabkan oleh dua faktor yaitu seberapa menarik pekerjaan yang ada saat ini dan tersedianya alternatif pekerjaan lain (Shaw, et al 1998). Sebaliknya involuntary turnover atau pemecatan menggambarkan keputusan pemberi kerja (employer) untuk menghentikan hubungan kerja dan bersifat uncontrollable bagi karyawan yang mengalaminya.

Dari beberapa pendapat para ahli diatas dapat didefinisikan bahwa niat untuk pindah kerja atau turnover intention adalah kecenderungan atau keinginan karyawan untuk berhenti bekerja dari pekerjaannya secara suka rela.

\section{Kategori Turnover Intention}

Menurut Abelson

mengelompokkan berhentinya karyawan dari perusahaan berdasarkan siapa yang memunculkan inisiatif untuk berhenti kerja, dalam 2 kategori :

a. Turnover yang terjadi sukarela (voluntary turnover)

Terjadi apabila karyawan memutuskan baik secara personal ataupun disebabkan oleh alasan profesional lainnya untuk menghentikan hubungan kerja dengan perusahaan, misalnya karyawan berkeinginan untuk mendapatkan pekerjaan dengan gaji yang lebih baik ditempat lain.

b. Turnover yang dipisahkan (involuntary turnover)
Menurut Abelson (1987) voluntary turnover dapat dibedakan atas dasar sifatnya menjadi avoidable voluntary turnover (dapat dihindarkan) dan unavoidable voluntary turnover (tidak dapat dihindarkan). Avoidable voluntary turnover timbul karena alasan upah yang lebih baik di perusahaan lain, kondisi kerja yang lebih baik di organisasi lain, prestasi kerja yang lebih baik di perusahaan lain, masalah dengan pimpinan/administrasi yang ada, serta adanya alternatif tempat pekerjaan lain. Unavoidable voluntary turnover timbul karena alasan pindah ke daerah lain karena mengikuti pasangan, perubahan arah karir individu, tinggal di rumah mengasuh anak dan kehamilan.

\section{Indikator Turnover Intention}

Menurut Lee dan Mowday (1987) menyatakan bahwa ada tiga indikator yang dapat digunakan untuk mengukur tinggirendahnya keinginan karyawan untuk keluar dari organisasi. Ketiga indikator tesebut adalah sebagai berikut:

a. Pikiran untuk keluar dari organisasi.

Saat karyawan merasa diperlakukan tidak adil, maka terlintas dalam pikiran mereka untuk keluar dari organisasi. Hal ini mengindikasikan bahwa perlakukan yang tidak adil akan menstimuli karyawan berpikir keluar dari organisasi.

b. Kemungkinan untuk mencari pekerjaan baru.

Ketidakmampuan suatu organisasi untuk memenuhi kebutuhan karyawan dapat memicu karyawan untuk berpikir mencari alternatif pekerjaan pada organisasi yang lain. Hal ini merupakan suatu konsekuensi logis saat suatu perusahaan tidak mampu memberikan/memenuhi kebutuhan karyawan seperti kemampuan perusahaan lain memiliki kemampuan yang baik dalam memenuhi kebutuhan karyawan.

c. Keaktifan dalam mencari pekerjaan baru. Salah satu indikator tingginya keinginan karyawan keluar dari organisasi adalah 
keaktifan seseorang mencari pekerjaan pada organisasi lain. Karyawan memiliki motivasi untuk mencari pekerjaan baru pada organisasi lain yang dianggap mampu memenuhi kebutuhan mereka (adil terhadap karyawan).

\section{Definisi Organizational Commitment}

Menurut Robbins (2001) komitmen organisasional adalah tingkatan dimana seorang pekerja mengidentifikasikan diri dengan organisasi dan tujuan-tujuannya dan berkeinginan untuk memelihara keanggotaannya dalam organisasi.

Menurut Sopiah (2008) menyebutkan bahwa komitmen organisasional merupakan identifikasi dan keterlibatan seseorang yang relatif kuat terhadap organisasi. Sopiah juga menambahkan bahwa komitmen organisasional adalah keinginan anggota untuk teteap mempertahankan keanggotaanya dalam organisasidan bersedia berusaha keras bagi bagi pencapaian tujuan organisasi.

Menurut Robbins (2006) mendefinisikan komitmen organisasional sebagai suatu keadaan dimana seorang karyawan mengkaitkan dirinya ke organisasi tertentu dan sasaran-sasarannya, dan berharap mempertahankan ke anggotaan dalam organisasi. Hal ini berdampak ketika seorang karyawan sedang menghadapi kondisi dimana karyawan tidak puas dengan pekerjaan tertentu dan menggangap hal tersebut sebagai kondisi sementara, secara implisit karyawan akan menunjukkan keberpihakannya atas keunggulan-keunggulan perusahaan tempat dia bekerja.

Menurut Cherrington (1994) komitmen organisasional adalah suatu nilai personal, dimana seringkali mengacu pada loyalitas terhadap perusahaan atau komitmen terhadap perusahaan. Konsep komitmen muncul dari studi yang mengeksplorasi kaitan/hubungan antara karyawan dan orang. Motivasi untuk melakukan studi terhadap komitmen didasari pada suatu keyakinan bahwa karyawan yang berkomitmen akan menguntungkan bagi perusahaan karena kemampuan potensialnya dan mengurangi turnover dan meningkatkan kinerja.

\section{Dimensi Komitmen Organisasional}

Menurut Meyer, Allen dan Smith (1993)

menyatakan bahwa komitmen organsasional merefleksikan tiga komponen umum, yaitu affective commitment, continuance commitment dan normative commitment. Karyawan dengan komitmen afektif yang kuat akan tetap bersama organisasi dalam hal ini perusahaan karena mereka menginginkannya, karyawan dengan komitmen berkelanjutan yang kuat karena mereka membutuhkannya, sedangkan karyawan dengan komitmen normatif yang kuat karena mereka merasa memiliki tanggung jawab yang besar terhadap perusahaan. Penjelasan mengenai ketiga komponen tersebut adalah:

a. Komitmen afektif (affective commitment) berkaitan dengan perasaaan emosional untuk organisasi dan keyakinan dalam nilai-nilainya.

b. Komitmen berkelanjutan (continuance commitment) berkaitan dengan nilai ekonomi yang dirasa dari bertahan dalam suatu organisasi bila dibandingkan dengan meninggalkan organisasi tersebut.

c. Komitmen normatif (normative commitment) merupakan kewajiban yang harus ia berikan kepada organisasi, kewajiban untuk bertahan dalam organisasi untuk alasan-alasan moral atau etis.

\section{Faktor-Faktor Yang Mempengaruhi Komitmen Organisasional}

Menurut Luthans (1995) dikatakan bahwa komitmen organisasi terdiri dari tiga faktor, yaitu:

a. Keinginan yang kuat untuk tetap menjadi anggota organisasi

b. Kemauan yang besar untuk berusaha bagi organisasi

c. Kepercayaan yang kuat dan penerimaan terhadap nilai dan tujuan organisasi.

Ketiga karakteristik ini menyatakan bahwa komitmen organisasi melibatkan lebih dari sekedar loyalitas yang pasif terhadap organisasi. Hal ini melibatkan 
suatu hubungan yang aktif dengan organisasi, dimana para karyawan mempunyai kemampuan untuk memberikan diri mereka dan membuat suatu kontribusi personal untuk membantu organisasi mencapai kesukesan. (Cherrington, 1994) Dalam review mereka tentang literatur-literatur mengenai komitmen organisasi,

Menurut Cherrington

mengidentifikasikan beberapa faktor yang mempengaruhi komitmen organisasional yang kemudian dirangkum dalam 4 kategori:

a. Faktor personal, dimana komitmen organisasi secara general lebih besar antara karyawan yang telah tua dan lama bekerja dalam organisai. Mereka yang mempunyai nilai kerja intrinsik lebih mempunyai komitmen. Dalam kelompok, karyawan wanita cenderung untuk lebih berkomitmen terhadap perusahaan dibandingkan karyawan lakilaki. Karyawan yang berpendidikan rendah cenderung untuk mempunyai komitmen lebih tinggi daripada karyawan yang berpendidikan tinggi.

b. Karakteristik peran, dimana komitmen akan cenderung lebih kuat bagi karyawan yang memiliki enriched jobs dan pekerjaan yang melibatkan tingkatan yang rendah dari konflik peran dan ambiguitas.

c. Karakteristik struktural, komitmen akan lebih kuat pada karyawan yang berada dalam organisasi yang terdesentralisasi dan dalam kerjasama antara pemilik kerja dimana karyawan tersebut lebih terlibat dalam pembuatan keputusan organisasi.

d. Pengalaman kerja, komitmen akan kuat untuk karyawan dengan pengalama kerja yang menyenangkan, seperti sikap positif dalam kelompok seseorang terhadap orang lain, perasaan bahwa organisasi dapat diandalkan untuk memenuhi komitmennya terhadap personil yang ada di dalamnya dan perasaan bahwa individu yang ada dalam organisasi merupakan hal yang penting bagi organisasi.

\section{Indikator Komitmen Organisasional}

Menurut Steers (1988) menjelaskan aspek-aspek yang dijadikan alat untuk mengukur komitmen organisasional adalah sebagai berikut:

a. Identification; tingkat sejauh mana merasa menjadi bagian dari sistem organisasi dimana tujuan organisasi menjadi tujuan setiap individu.

b. Involvement; tingkat keterlibatan dalam mengambil keputusan.

c. Loyality; niatan untuk tetap menjadi anggota organisasi, kesetiaan dan kebanggaan terhadap organisasi.

\section{Definisi Kepuasan Gaji}

Menurut Lum et al (1999) menyatakan bahwa kepuasan gaji dapat diartikan bahwa seseorang akan terpuaskan dengan gajinya ketika persepsi terhadap gaji dan apa yang mereka peroleh sesuai dengan yang diharapkan. Beberapa penelitian mengidentifikasi aspek kepuasan yang ditemukan berhubungan dengan keinginan individu untuk meninggalkan organisasi meliputi kepuasan akan upah dan promosi.

Gaji dipandang sebagai bagian dari sistem yang mendukung yang digunakan oleh organisasi untuk memotivasi karyawan dengan memenuhi aturan dan peraturan. Bagi pekerja, gaji dipandang sebagai suatu outcome atau reward yang penting. Karyawan merasa puas dengan gajinya apabila sistem gaji dalam perusahaan tersebut mempertimbangan penentuan gaji juga tidak hanya memperhatikan prinsip Internally Equitable (keadilan di dalam perusahaan) yang dibuat berdasarkan azas keadilan tetapi juga harus mempunyai nilai yang kompetitif di pasar (Externally Equitable).

Menurut Heneman dan Schwab (1986) kepuasan gaji dapat diartikan bahwa seseorang akan terpuaskan dengan gajinya ketika persepsi terhadap gaji dan apa yang mereka peroleh sesuai dengan yang diharapkan. Beberapa penelitian mengidentifikasi aspek kepuasan yang ditemukan berhubungan dengan keinginan individu untuk meninggalkan organisasi 
meliputi kepuasan akan upah dan promosi. Kepuasan gaji merupakan konstruk kepuasan yang multi dimensi yang terdiri atas empat sub dimensi: tingkat gaji (pay level), struktur/pengelolaan gaji (pay structure and administration), peningkatan gaji (pay raise) dan tunjangan (benefit).

Menurut Endang Hersusdadikawati (2004:89) kepuasan atas tingkat gaji didefinisikan sebagai persepsi kepuasan atas gaji atau upah langsung, sedangkan kepuasan atas struktur atau pengadministrasian gaji didefinisikan sebagai persepsi kepuasan dengan hirarki gaji internal dan metode yang digunakan untuk mendistribusikan gaji. Kepuasan atas peningkatan gaji berkenaan dengan persepsi kepuasan dalam perubahan tingkat gaji. Kepuasan atas tunjangan menekankan pada persepsi kepuasan dengan pembayaran tidak langsung yang diterima karyawan.

Kepuasan individu atas gaji yang diterima didasarkan pada teori equity yang berkenaan dengan motivasi individu untuk bertindak dalam organisasi. Individu akan menilai rasio input terhadap outcome bagi tugas yang ada dan membandingkannya dengan referent (misalnya: upah lembur). Untuk menuju pada keadilan (equity) outcome atau input dapat diubah, secara objektif atau psikologis dapat merubah referent pembanding, individu dapat menarik diri dari situasi atau terjadinya turnover. Teori equity menekankan bahwa kepuasan gaji disebabkan oleh perasaan yang berhubungan dengan rasa keadilan atas gaji yang dibayarkan. Perasaan ini merupakan hasil dari proses yang terus menerus dan setelah membandingkannya dengan outcome yang lain. Teori ini didasari bahwa seorang pekerja memformulasikan rasio outcome-nya (termasuk gaji) dengan input. Rasio ini kemudian dibandingkan dengan rasio outcome (input) dari beberapa sumber yang menjadi acuan. Jika gaji yang diterima pekerja kurang dari lainnnya, akan menimbulkan adanya perasaan diperlakukan tidak adil (inequitabel) atas pembayaran yang diberikan.

\section{Tujuan Pengupahan/Penggajian}

Menurut Hasibuan (2002) tujuan pengupahan/penggajian antara lain adalah :

a. Ikatan kerja sama; dengan pemberian gaji terjalinlah ikatan kerja sama formal antara majikan dengan karyawan. Karyawan harus mengerjakan tugastugasnya dengan baik, sedangkan pengusaha atau majikan wajib membayar gaji sesuai dengan perjanjian yang disepakati.

d. Pengadaan efektif; jika program gaji ditetapkan cukup besar, pengadaan karyawan yang qualified untuk perusahaan akan lebih mudah.

e. Motivasi; jika balas jasa yang diberikan cukup besar, manajer akan mudah memotivasi bawahannya.

f. Kepuasan kerja; dengan balas jasa, karyawan akan dapat memenuhi kebutuhan - kebutuhan fisik, status sosial, dan egoistiknya sehingga memperoleh kepuasan kerja dari jabatannya.

g. Stabilitas karyawan; dengan program kompensasi atas prinsip adil dan layak serta eksternal konsistensi yang kompentatif maka stabilitas karyawan lebih terjamin karena turnover relatif kecil.

h. Pengaruh serikat buruh; dengan program kompensasi yang baik pengaruh serikat buruh dapat dihindarkan dan karyawan akan berkonsentrasi pada pekerjaannya.

i. Disiplin; dengan pemberian balas jasa yang cukup besar maka disiplin karyawan semakin baik. Karyawan akan menyadari serta mentaati peraturanperaturan yang berlaku.

j. Pengaruh pemerintah; jika program gaji sesuai dengan undang-undang yang berlaku (seperti batas gaji minimum) maka intervensi pemerintah dapat dihindarkan. ikatan kerja, kepuasan kerja, pengadaan efektif, motivasi, stabilitas karyawan, disiplin, serta pengaruh serikat buruh dan pemerintah. 


\section{Asas Pengupahan/Penggajian}

Menurut Hasibuan (2009) program pengupahan/penggajian ditinjau dari 2 asas yaitu:

a. Asas adil; artinya adalah besarnya upah/gaji yang dibayar kepada setiap karyawan harus disesuaikan dengan prestasi kerja, jenis pekerjaan, risiko pekerjaan, tanggung jawab, jabatan pekerja, dan memenuhi persyaratan internal konsistensi. Jadi adil bukan berarti setiap karyawan menerima upah/gaji yang sama besarnya.

b. Asas layak; artinya adalah upah/gaji yang diterima karyawan dapat memenuhi kebutuhannya pada tingkat normatif yang ideal. Tolok ukur layak adalah relatif, penetapan besarnya upah/gaji didasarkan atas batas upah minimal pemerintah dan eksternal konsistensi yang berlaku.

\section{Indikator Kepuasan Gaji}

Indikator kepuasan gaji dapat dipakai menurut teori ekuitas Adams (1965) kepuasan gaji mempunyai beberapa indikator, antara lain:

a. Economic need atau memenuhi kebutuhan ekonomi keluarga.

b. Ekuitas disebabkan karena perasaan mengenai ekuitas (keadilan/kewajaran) dalam penghasilan seseorang. Perasaan tersebut berasal dari perbandingan (komparatif) rasio pengeluaran penghasilan terhadap input penghasilan. Jika rasio tersebut cocok, keadilan/kewajaran penghasilan dan kepuasan akan dicapai.

c. Organizational support atau perhatian pihak organisasi atas penyesuaian gaji terhadap kebutuhan hidup. Gaji yang diterima sesuai dengan peraturan sistem penggajian antara usaha/kerja dan pelaksanaannya oleh bagian keuangan.

\section{Definisi Kepuasan Kerja}

Menurut Robbins (2001) kepuasan kerja merupakan sikap umum individu terhadap pekerjaannya atau penilaian karyawan atas seberapa puas atau tidak puas dirinya dengan pekerjaannya.
Menurut Kreitner dan Kinicki (2005) kepuasan kerja merupakan hal yang bersifat individual. Setiap individu mempunyai tingkat kepuasan yang berbeda-beda, bahwa kepuasan kerja sebagai efektivitas atau respons emosional terhadap berbagai aspek pekerjaan. Definisi ini mengandung pengertian bahwa kepuasan kerja bukanlah suatu konsep tunggal sebaliknya seseorang dapat relatif puas dengan suatu aspek dari pekerjaannya dan tidak puas dengan salah satu atau beberapa aspek lainnya.

Menurut Luthans (2006) dalam berpendapat bahwa kepuasan kerja adalah perasaan pekerja atau karyawan yang berhubungan dengan pekerjaannya yaitu merasa senang atau tidak senang, sebagai hasil penilaian individu yang bersangkutan terhadap pekerjaannya.

Menurut Handoko (1998) kepuasan kerja adalah keadaan emosional yang menyenangkan atau tidak menyenangkan dengan mana karyawan memandang pekerjaannya.

\section{Teori-Teori Kepuasan Kerja}

Teori-teori kepuasan kerja menurut Anwar Prabu (1993) yaitu:

a. Teori ketidaksesuaian (dicrepany theory) Teori ini dipelopori oleh Porter, Porter mengukur kepuasan kerja seseorang dengan memperhitungkan selisih antara yang seharusnya dengan kenyataan yang dirasakan. Kerja seseorang bergantung kepada ketidak sesuaian antara apa yang seharusnya (harapan, keinginan, atau nilai-nilai) dengan apa yang menurut perasaannya atau persepsinya telah diperoleh atau dicapai melalui pekerjaan.

b. Teori keadilan (equity theory)

Equity theory (teori keadilan) dikembangkan oleh Adams. Adapun pendahulu dari teori ini adalah Zabznik. Prinsip dari teori ini adalah bahwa orang akan merasa puas dan tidak puas tergantung apakah ia merasakan adanya keadilan (equity) atau tidak atas suatu situasi. Perasaan adil dan tidak adil atas suatu situasi, diperoleh dengan cara 
membandingkan dirinya dengan orang lain, dan keadilan dengan ketidakadilan.

c. Teori dua faktor (two factor theory)

Prinsip dari teori ini adalah bahwa kepuasan kerja dan ketidakpuasan merupakan dua hal yang berbeda, artinya kepuasan dan ketidakpuasan terhadap pekerjaan itu tidak merupakan suatu variabel yang berkelanjutan. Herzberg membagi situasi yang mempengaruhi sikap seseorang terhadap pekerjaannya menjadi 2 kelompok: kelompok satisfier atau motivator dan kelompok disatisfiers atau hygiene factor.

\section{Dimensi Kepuasan Kerja}

Menurut Luthans (2006) terdapat lima dimensi kepuasan kerja yang dapat merepresentasikan respons kepuasan kerja karyawan, diantaranya yaitu:

a. Pekerjaan itu sendiri.

Kepuasan pekerjaan itu sendiri merupakan sumber utama kepuasan, dimana pekerjaan tersebut memberikan tugas yang menarik, kesempatan untuk belajar, kesempatan untuk menerima tanggung jawab dan kemajuan untuk karyawan. Penelitian terbaru menemukan bahwa karakteristik pekerjaan dan kompleksitas pekerjaan menghubungkan antara kepribadian dan kepuasan kerja. Jika persyaratan kreatif pekerjaan terpenuhi, maka mereka cenderung menjadi puas. Selain itu, perkembangan karir (tidak perlu promosi) merupakan hal penting untuk karyawan muda dan tua.

b. Gaji

Gaji sebagai faktor multidimensi dalam kepuasan kerja merupakan sejumlah upah/ uang yang diterima dan tingkat dimana hal ini bisa dipandang sebagai hal yang dianggap pantas dibandingkan dengan orang lain dalam organisasi. Uang tidak hanya membantu orang memperoleh kebutuhan dasar, tetapi juga alat untuk memberikan kebutuhan kepuasan pada tingkat yang lebih tinggi. Karyawan melihat gaji sebagai refleksi dari bagaimana manajemen memandang kontribusi mereka terhadap perusahaan. Jika karyawan fleksibel dalam memilih jenis benefit yang mereka sukai dalam sebuah paket total (rencana benefit fleksibel), maka ada peningkatan signifikan dalam kepuasan benefit dan kepuasan kerja secara keseluruhan.

c. Kesempatan promosi.

Kesempatan promosi adalah kesempatan untuk maju dalam organisasi, sepertinya memiliki pengaruh yang berbeda pada kepuasan kerja. Hal ini dikarenakan promosi memiliki sejumlah bentuk yang berbeda dan memiliki penghargaan, seperti promosi atas dasar senioritas atau kinerja dan promosi kenaikan gaji. Lingkungan kerja yang positif dan kesempatan untuk berkembang secara intelektual dan memperluas keahlian dasar menjadi lebih penting daripada kesempatan promosi.

d. Pengawasan.

Pengawasan merupakan kemampuan penyelia untuk memberikan bantuan teknis dan dukungan perilaku. Ada 2 (dua) dimensi gaya pengawasan yang dapat mempengaruhi kepuasan kerja. Yang pertama adalah berpusat pada karyawan, diukur menurut tingkat dimana penyelia menggunakan ketertarikan personal dan peduli pada karyawan, seperti memberikan nasehat dan bantuan kepada karyawan, komunikasi yang baik dan meneliti seberapa baik kerja karyawan. Yang kedua adalah iklim partisipasi atau pengaruh dalam pengambilan keputusan yang dapat mempengaruhi pekerjaan karyawan. Secara umum, kedua dimensi tersebut sangat berpengaruh pada kepuasan kerja karyawan.

e. Rekan kerja.

Pada umumnya, rekan kerja yang kooperatif merupakan sumber kepuasan kerja yang paling sederhana pada karyawan secara individu. Kelompok kerja, terutama tim yang 'kuat' bertindak sebagai sumber dukungan, kenyamanan, nasehat dan bantuan pada anggota individu. Karena kelompok kerja 
memerlukan kesalingtergantungan antar anggota dalam menyelesaikan pekerjaan. Kondisi seperti itulah efektif membuat pekerjaan menjadi lebih menyenangkan, sehingga membawa efek positif yang tingggi pada kepuasan kerja.

Menurut Kreitner dan Knicki (2003) menjelaskan penyebab dari kepuasan kerja adalah pemenuhan kebutuhan, ketidakcocokan, pencapaian nilai, persamaan, dan komponen watak atau genetik. Adapun ulasan singkat dari model itu adalah:

a. Pemenuhan kebutuhan, model ini menjelaskan bahwa kepuasan kerja ditentukan oleh karakteristik dari sebuah pekerjaan yang memungkinkan seorang individu untuk memenuhi kebutuhannya. Kebutuhan yang tidak dapat terpenuhi dapat mempengaruhi kepuasan maupun berhentinya karyawan. Walaupun model-model ini memunculkan sejumlah besar kontroversi, tetapi secara umum diterima bahwa pemenuhan kebutuhan memiliki korelasi dengan kepuasan kerja.

b. Ketidakcocokan, menjelaskan bahwa kepuasan kerja adalah hasil dari harapan yang tidak terpenuhi. Harapan yang terpenuhi mewakili perbedaan antara apa yang diharapkan oleh seorang individu dari sebuah pekerjaan, seperti upah dan kesempatan promosi yang baik dan apa yang pada kenyataannya diterimanya. Pada saat harapan lebih besar daripada yang diterima seseorang akan tidak puas.

c. Pencapaian nilai, gagasan yang melandasi pencapaian nilai adalah kepuasan yang berasal dari persepsi bahwa suatu pekerjaan memungkinkan untuk pemenuhan nilai secara positif berkaitan dengan kepuasan kerja. Oleh karena itu pimpinan organisasi atau perusahaan dapat meningkatkan kepuasan karyawan dengan melakukan strukturisasi lingkungan kerja penghargaan dan pengakuan yang berhubungan dengan nilai-nilai karyawan.

d. Persamaan, dalam model ini kepuasan adalah suatu fungsi dari bagaimana seorang individu diperlakukan "secara adil" di tempat kerja. Kepuasan berasal dari persepsi seseorang bahwa output pekerjaan, relatif sama dengan inputnya, perbandingan yang mendukung output atau input lain yang signifikan. Para karyawan merasakan keadilan terhadap upah dan promosi secara signifikan berkorelasi dengan kepuasan kerja.

e. Komponen watak atau genetik, model ini berusaha menjelaskan berbagai situasi kerja yang secara khusus didasarkan pada keyakinan bahwa kepuasan kerja merupakan fungsi dari sifat pribadi atau faktor genetik. Oleh karena itu model ini menunjukkan bahwa perbedaan individu yang stabil adalah sama pentingnya dalam menjelaskan kepuasan kerja dengan karakteristik lingkungan kerja.

Menurut Ghiselli dan Brown dalam As'ad (1978) ada lima faktor yang menimbulkan kepuasan kerja yaitu antara lain:

a. Kedudukan

b. Pangkat atau golongan

c. Jaminan finansial dan jaminan sosial

d. Mutu pengawasan.

e. Umur orang sewaktu bekerja

\section{Indikator Kepuasan Kerja}

Menurut Luthans (2006) kepuasan kerja mempunyai beberapa indikator antara lain:

a. Gaji; sejumlah upah yang diterima dan tingkat dimana hal ini bisa dipandang sebagai hal yang dianggap pantas dibandingkan dengan orang lain dalam organisasi.

b. Kesempatan promosi; kesempatan untuk maju dalam organisasi.

c. Rekan kerja; tingkat dimana rekan kerja pandai secara teknis dan mendukung secara sosial. 
d. Pengawasan; kemampuan penyelia untuk memberikan bantuan teknis dan dukungan perilaku.

e. Pekerjaan itu sendiri; dalam hal dimana pekerjaan memberikan tugas yang menarik, kesempatan untuk belajar dan kesempatan untuk menerima tanggung jawab.

\section{Aspek-Aspek Lain Yang Terdapat Dalam Kepuasan Kerja}

Menurut Robbins (2001) kepuasan kerja mempunyai beberapa aspek antara lain:

a. Kerja yang secara mental menantang. Kebanyakan karyawan menyukai pekerjaan-pekerjaan yang memberi mereka kesempatan untuk menggunakan keterampilan dan kemampuan mereka dan menawarkan tugas, kebebasan dan umpan balik mengenai betapa baik mereka mengerjakan. Karakteristik ini membuat kerja secara mental menantang. Pekerjaan yang terlalu kurang menantang menciptakan kebosanan, tetapi terlalu banyak menantang menciptakan frustasi dan perasaan gagal. Pada kondisi tantangan yang sedang, kebanyakan karyawan akan mengalamai kesenangan dan kepuasan.

b. Ganjaran yang pantas.

Para karyawan menginginkan sistem upah dan kebijakan promosi yang mereka persepsikan sebagai adil, dan segaris dengan pengharapan mereka. Pemberian upah yang baik didasarkan pada tuntutan pekerjaan, tingkat keterampilan individu, dan standar pengupahan komunitas, kemungkinan besar akan dihasilkan kepuasan. tidak semua orang mengejar uang. Banyak orang bersedia menerima baik uang yang lebih kecil untuk bekerja dalam lokasi yang lebih diinginkan atau dalam pekerjaan yang kurang menuntut atau mempunyai keleluasaan yang lebih besar dalam kerja yang mereka lakukan dan jam-jam kerja. Tetapi kunci yang manakutkan upah dengan kepuasan bukanlah jumlah mutlak yang dibayarkan, yang lebih penting adalah persepsi keadilan. Serupa pula karyawan berusaha mendapatkan kebijakan dan praktik promosi yang lebih banyak, dan status sosial yang ditingkatkan. Oleh karena itu, individu-individu yang mempersepsikan bahwa keputusan promosi dibuat dalam cara yang adil (fair and just) kemungkinan besar akan mengalami kepuasan dari pekerjaan mereka.

c. Kondisi kerja yang mendukung.

Karyawan peduli akan lingkungan kerja baik untuk kenyamanan pribadi maupun untuk memudahkan mengerjakan tugas. Studi-studi memperagakan bahwa karyawan lebih menyukai keadaan sekitar fisik yang tidak berbahaya atau merepotkan. Temperatur, cahaya, kebisingan, dan faktor lingkungan lain.

d. Rekan kerja yang mendukung.

Orang-orang mendapatkan lebih daripada sekedar uang atau prestasi yang berwujud dari dalam kerja. Bagi kebanyakan karyawan, kerja juga mengisi kebutuhan akan sosial. Oleh karena itu, bila mempunyai rekan sekerja yang ramah dan menyenagkan dapat menciptakan kepuasan kerja yang meningkat. Tetapi Perilaku atasan juga merupakan determinan utama dari kepuasan.

e. Kesesuaian kepribadian dengan pekerjaan.

Pada hakikatnya orang yang tipe kepribadiannya kongruen (sama dan sebangun) dengan pekerjaan yang mereka pilih seharusnya mendapatkan bahwa mereka mempunyai bakat dan kemampuan yang tepat untuk memenuhi tuntutan dari pekerjaan mereka. Dengan demikian akan lebih besar kemungkinan untuk berhasil pada pekerjaan tersebut, dan karena sukses ini, mempunyai kebolehjadian yang lebih besar untuk mencapai kepuasan yang tinggi dari dalam kerja mereka. 
Gambar 1

Kerangka Penelitian

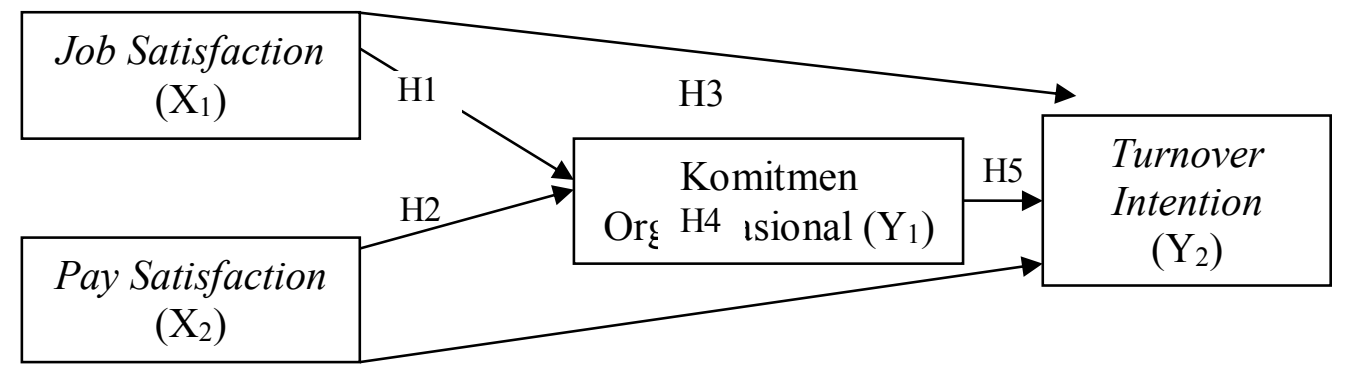

Hipotesis

$\mathrm{H}_{1}$ : Job satisfaction berpengaruh terhadap komitmen organisasional karyawan Bale Group Kebumen.

$\mathrm{H}_{2}$ : Pay satisfaction berpengaruh terhadap komitmen organisasional karyawan Bale Group Kebumen.

$\mathrm{H}_{3}$ : Job satisfaction berpengaruh terhadap turnover intention karyawan Bale Group Kebumen.

$\mathrm{H}_{4}$ : Pay satisfaction berpengaruh terhadap turnover intention karyawan Bale Group Kebumen

$\mathrm{H}_{5}$ : Komitmen organisasional berpengaruh terhadap turnover intention karyawan Bale Group Kebumen

\section{Obyek Penelitian}

Obyek penelitian ini adalah variabel job satisfaction (kepuasan kerja), pay satisfaction (kepuasan gaji), komitmen organisasional dan turnover intention (niat untuk pindah kerja).

\section{Subyek Penelitian}

Subyek penelitian ini adalah karyawan tetap Bale Group Kebumen yang berjumlah 108 orang.

\section{Variabel Penelitian}

Variabel penelitian adalah suatu atribut atau sifat dari orang, objek, atau kegiatan yang mempunyai variasi tertentu yang ditetapkan oleh penelitian untuk dipelajari dan ditarik kesimpulan (Sugiyono, 2004). Berdasarkan model yang dikembangkan, variabel yang terdapat pada penelitian ini yaitu:

\section{Variabel Independen \\ Variabel independen adalah variabel yang menjadi sebab atau berubahnya suatu variabel lain. Variabel bebas dalam penelitian ini adalah job satisfaction $\left(\mathrm{X}_{1}\right)$, dan pay satisfaction $\left(\mathrm{X}_{2}\right)$.}

2. Variabel Intervening

Variabel intervening adalah variabel antara yang menghubungkan variabel terikat dan variabel bebas. Dalam penelitian ini yang menjadi variabel intervening adalah komitmen organisasional $\left(\mathrm{Y}_{1}\right)$.

\section{Variabel Dependen}

Variabel dependen merupakan variabel yang dipengaruhi atau menjadi akibat karena variabel lain (variabel bebas). Variabel dependen dari penelitian ini adalah Dalam penelitian ini yang menjadi variabel dependen adalah turnover intention $\left(\mathrm{Y}_{2}\right)$.

\section{Definisi Operasional Variabel}

Definisi operasional variabel merupakan suatu definisi yang diberikan kepada suatu variabel dengan cara memberi arti atau menspesifikasikan kegiatan ataupun memberikan suatu operasional yang diperlukan untuk mengukur variabel tersebut. Definisi operasional diperlukan untuk memudahkan melakukan pengukuran dan menghindari penafsiran yang berbeda. 
Adapun definisi operasional variabel untuk setiap variabel adalah sebagai berikut:

1. Turnover intention (niat untuk pindah kerja)

Turnover intention atau niat untuk pindah kerja didefinisikan sebagai penarikan diri secara sukarela

Tabel

Indikator dan Distribusi Variabel Turnover Intention pada Kuesioner

\begin{tabular}{|c|l|c|c|}
\hline No. & \multicolumn{1}{|c|}{ Indikator } & $\begin{array}{c}\text { Distribusi } \\
\text { Butir Ke - }\end{array}$ & Jumlah \\
\hline 1. & Pikiran untuk keluar dari organisasi. & $1-2$ & 2 \\
\hline 2. & Kemungkinan untuk mencari pekerjaan baru. & $3-4$ & 2 \\
\hline 3. & Keaktifan dalam mencari pekerjaan baru. & $5-6$ & 2 \\
\hline \multicolumn{2}{|c|}{ Jumlah } & $\mathbf{6}$ \\
\hline
\end{tabular}

2. Organizational commitment (komitmen organisasional)

Komitmen organisasional adalah tingkatan dimana seorang pekerja mengidentifikasikan diri dengan organisasi dan tujuan-tujuannya dan

Tabel (voluntary) atau tidak sukarela (involuntary) dari suatu organisasi (Robbins, 1996). Indikator turnover intention (niat untuk pindah kerja) yang digunakan dalam penelitian ini antara lain (Lee dan Mowday, 1987):

\section{Indikator dan Distribusi Variabel Komitmen Organisasional pada Kuesioner}

\begin{tabular}{|c|l|c|c|}
\hline No. & \multicolumn{1}{|c|}{ Indikator } & $\begin{array}{c}\text { Distribusi } \\
\text { Butir Ke - }\end{array}$ & Jumlah \\
\hline 1. & Identification (Identifikasi). & 1 & 1 \\
\hline 2. & Involvement (Keterlibatan). & 2 & 1 \\
\hline 3. & Loyality (Loyalitas) Jumlah & 3 & 1 \\
\hline \multicolumn{2}{|c|}{ J } \\
\hline
\end{tabular}

\section{Pay satisfaction (kepuasan gaji)}

Pay satisfaction atau kepuasan gaji dapat diartikan bahwa seseorang akan terpuaskan dengan gajinya ketika persepsi terhadap gaji dan apa yang berkeinginan untuk memelihara keanggotaannya dalam organisasi (Robbins, 2001). Indikator komitmen organisasional yang digunakan dalam penelitian ini antara lain Steers (1988) : 


\begin{tabular}{|c|l|c|c|}
\hline 3. & Organizational support. & $3-4$ & 2 \\
\hline \multicolumn{2}{|c|}{ Jumlah } & $\mathbf{4}$ \\
\hline
\end{tabular}

\section{Job satisfaction (kepuasan kerja)}

Job satisfaction atau kepuasan kerja merupakan sikap umum individu terhadap pekerjaannya atau penilaian karyawan atas seberapa puas atau tidak puas dirinya dengan pekerjaannya (Robbins, 2001). Indikator job satisfaction (kepuasan kerja) yang digunakan dalam penelitian ini antara lain Luthans (2006):

a. Gaji

b. Kesempatan promosi.

c. Rekan kerja.

d. Pengawasan.

yang digunakan pada penelitian ini menjadi:

Tabel
Untuk kepentingan analisis data dalam penelitian ini, indikator job satisfaction (kepuasan kerja) yang pertama yaitu gaji tidak digunakan karena akan digunakan sebagai indikator pada variabel pay satisfaction (kepuasan gaji). Hal ini dilakukan untuk menghindari adanya multikolinearitas antara variabel job satisfaction (kepuasan kerja) dan variabel pay satisfaction (kepuasan gaji). Oleh karena itu indikator job satisfaction (kepuasan kerja)

Indikator dan Distribusi Variabel job Satisfaction pada Kuesioner

\begin{tabular}{|c|l|c|c|}
\hline No. & \multicolumn{1}{|c|}{ Indikator } & $\begin{array}{c}\text { Distribusi } \\
\text { Butir Ke - }\end{array}$ & Jumlah \\
\hline 1. & Kesempatan promosi. & 1 & 1 \\
\hline 2. & Rekan kerja. & 2 & 1 \\
\hline 3. & Pengawasan. & 3 & 1 \\
\hline 4. & Pekerjaan itu sendiri. & 4 & 1 \\
\hline \multicolumn{2}{|c|}{ Jumlah } & $\mathbf{4}$ \\
\hline
\end{tabular}

\section{Populasi dan Sampel Penelitian Populasi}

Populasi adalah wilayah generalisasi yang mempunyai kualitas dan karakteristik tertentu yang ditetapkan oleh peneliti untuk dipelajari dan kemudian ditarik kesimpulannya (Sugiyono, 2008:80). Dalam penelitian ini yang menjadi populasi adalah seluruh karyawan tetap Bale Group Kebumen yang berjumlah 108 orang. Karakteristik populasi di dalam penelitian ini adalah:

1. Karyawan tetap Bale Group Kebumen.

Karyawan yang menjadi subjek penelitian ini adalah karyawan tetap, bukan karyawan kontrak maupun honorer. Karyawan tetap diasumsikan memiliki rasa keterikatan terhadap perusahaan yang lebih tinggi bila dibandingkan dengan karyawan kontrak atupun honorer.

2. Karyawan tetap Bale Group Kebumen dengan masa kerja minimal satu tahun.
Karyawan dengan masa kerja minimal satu tahun diasumsikan telah mengalami penyesuaian yang relatif stabil terhadap nilai-nilai organisasi.

\section{Sampel}

Sampel adalah sebagian dari jumlah dan karakteristik yang dimiliki oleh populasi tersebut (Sugiyono, 2010:118). Adapun jumlah responden dalam penelitian ini adalah 108 orang.

\section{Teknik Pengambilan Sampel}

Peneliti menggunakan metode sampling jenuh/sensus yaitu memakai semua anggota populasi sebagai obyek penelitian, karena dalam penelitian ini peneliti menggunakan alat analisis Structural Equation Modeling (SEM) sehingga dinyatakan telah memenuhi syarat minimal. Menurut Ferdinand (2006) menyebutkan bahwa jumlah sampel yang representatif untuk menggunakan teknik analisis SEM adalah 100-200. Hair et al., 
(1995) Ferdinand (2006) dalam menyarankan rumus untuk menentukan jumlah sampel yang diambil untuk suatu penelitian 5 sampai 10 kali dari jumlah indikator yang dipergunakan dalam penelitian. Indikator dalam penelitian ini adalah 17. Maka ketika dikalikan dengan 5 dan 10, masih memenuhi kriteria jumlah sampel.

Dengan mengacu pada pendapat Hair maka jumlah sampel yang digunakan dalam penelitian ini adalah 102 responden. Dalam penelitian ini, pimpinan tidak termasuk responden karena penelitian ini berfokus untuk meneliti tentang turnover intention karyawan.

\section{Teknik Analisis Data}

Teknik analisis data merangkum sejumlah data besar yang dapat memperoleh informasi tentang pemahaman karakteristik responden atau sifat-sifat data tersebut dan menjawab permasalahan dalam kegiatan penelitian. Teknik analisis data yang digunakan dalam penelitian ini adalah:

\section{Analisis Deskriptif}

Analisis deskriptif digunakan berdasarkan pandangan dan pemikiran secara teoritis yang disajikan dalam bentuk keterangan dan penjelasan yang sifatnya non statistik. Menurut Sugiyono (2008:105) menyatakan metode analisis deskriptif merupakan metode penelitian dengan cara mengumpulkan datadata sesuai dengan yang sebenarnya kemudian data-data tersebut disusun, diolah dan dianalisis untuk dapat memberikan gambaran mengenai masalah yang ada.

\section{Analisis Statistika}

Analisis statistika adalah metode analisis data dengan menggunakan angka-angka yang diperolah dari pengolahan data melalui rumus yang tepat. Adapun analisis yang digunakan meliputi :

\section{Uji Validitas}

Uji validitas digunakan untuk mengukur sah atau valid tidaknya suatu kuesioner (Ghozali, 2009). Suatu kuesioner dikatakan valid jika pertanyaan pada kuesioner mampu untuk mengungkapkan sesuatu yang akan diukur oleh kuesioner tersebut. Jadi, validitas adalah mengukur apakah pertanyaan dalam kuesioner yang sudah dibuat betul-betul dapat mengukur apa yang hendak diukur. Analisis terhadap hasil uji validitas pada penelitian ini dengan menggunakan bantuan programisasi komputer dengan program SPSS 22.0 for Windows, menggunakan Pearson Corelation seperti yang dikemukakan oleh Arikunto (2002) adalah sebagai berikut:

$$
\mathbf{r}=\frac{\mathbf{n} \sum \mathbf{X Y}-\left(\sum \mathbf{X}\right)\left(\sum \mathbf{Y}\right)}{\sqrt{\left[\mathbf{n} \sum \mathbf{X}^{2}-\left(\sum \mathbf{X}\right)^{2}\right]\left[\mathbf{n} \sum \mathbf{Y}^{2}-\left(\sum \mathbf{Y}\right)^{2}\right]}}
$$

Dimana:

$\mathrm{r} \quad=$ koefisien korelasi variabel bebas dan variabel terikat

$\mathrm{n}=$ banyaknya sampel/jumlah responden

$\mathrm{X}=$ skor tiap item yang dipertanyakan

$\mathrm{Y}=$ skor total variabel

Dengan level of significance 95\% maka bila:

a. $\quad r_{\text {hitung }}>r_{\text {tabel }}(\alpha=0,05)$ berarti item tersebut sangat valid

b. $\quad r_{\text {hitung }}<r_{\text {tabel }}(\alpha=0,05)$ berarti item tersebut tidak valid

\section{Uji Reliabilitas}

Reliabilitas adalah alat untuk mengukur suatu kuesioner yang merupakan indikator dari variabel atau konstruk (Ghozali, 2009). Suatu kuesioner dikatakan reliabel atau handal jika jawaban seseorang terhadap pernyataan adalah konsisten atau stabil dari waktu ke waktu. Jawaban responden terhadap pertanyaan ini dikatakan reliabel jika masing-masing pertanyaan dijawab secara konsisten atau jawaban tidak boleh acak oleh karena masing-masing pertanyaan hendak mengukur hal yang sama. Jika jawaban terhadap indikator ini acak (tidak konsisten), maka dapat dikatakan bahwa tidak reliabel (Ghozali, 2009). Pengukuran realibilitas dapat dilakukan dengan One Shot atau pengukuran sekali saja. Disini pengukurannya hanya sekali dan kemudian hasilnya dibandingkan dengan pertanyaan 
lain atau mengukur korelasi antar jawaban pertanyaan. Alat untuk mengukur reliabilitas adalah Alpha Cronbach. Analisis terhadap hasil uji reliabilitas pada penelitian ini dengan menggunakan

Dimana:

$\mathrm{r}_{11}=$ Reliabilitas instrumen

$\mathrm{k}=$ Banyaknya butir pertanyaan

$\sum \sigma b^{2}=$ Jumlah varian butir

$\sigma \tau^{2} \quad=$ Total varian

Kriteria pengujian uji realibilitas (Ghozali, 2009) :

a. Jika Alpha Cronbach $>0,60$ atau $60 \%$, maka butir atau variabel tersebut reliabel.

b. Jika Alpha Cronbarch $<0,60$ atau $60 \%$, maka variabel tersebut tidak reliabel.

\section{SEM (Structural Equation Model).}

Suatu penelitian membutuhkan analisis data dan interpretasinya yang bertujuan menjawab pertanyaan-pertanyaan peneliti dalam rangka mengungakap fenomena sosial tertentu. Analisis data adalah proses penyederhanaan data ke dalam bentuk yang lebih mudah dibaca dan dinterpretasikan. Metode yang dipilih untuk analisis data harus sesuai dengan pola penelitian dan variabel yang akan diteliti. Pengujian hipotesis dalam penelitian ini menggunakan alat analisis data Structural Equation Modeling dari paket statistik AMOS 21.0 for Windows. Sebagai sebuah model persamaan struktur, amos sering digunakan dalam penelitianpenelitian pemasaran dan manajemen strategik (Ferdinand, 2006). Model kausal amos menunjukkan pengukuran dan masalah yang struktural, dan digunakan untuk menganalisis dan menguji model hipotesis. Menurut Arbuckle dan Bacon dalam Ferdinand (2006) amos mempunyai keistimewaan dalam:

a. Memperkirakan koefisien yang tidak diketahui dari persamaan linear struktural. bantuan programisasi komputer dengan program SPSS 22.0 for Windows, yang mengacu pada rumus Alpha Cronbach berikut: $\left.-\frac{\sum \sigma \mathbf{b}^{2}}{\sigma \mathbf{\tau}^{2}}\right)$

b. Mengakomodasi model yang meliputi latent variabel.

c. Mengakomodasi kesalahan pengukuran pada variabel dependen dan independen.

d. Mengakomodasi peringatan yang timbal balik, simultan dan saling ketergantungan.

Penelitian ini menggunakan dua macam teknik analisis yaitu:

a. Analisis Faktor Konfirmatori (Confirmatory Factor Analysis)

Analisis faktor konfirmatori pada SEM digunakan untuk mengkonfirmasikan faktor-faktor yang paling dominan dalam satu kelompok variabel. Pada penelitian ini analisis faktor konfirmatori digunakan untuk menguji indikator yang membentuk job satisfaction, pay satisfaction, komitmen organisasional dan turnover intention.

b. Regression weight

Regression weight pada SEM digunakan untuk meneliti seberapa besar pengaruh hubungan variabelvariabel yang secara teoritis ada. Dalam penelitian ini varibelvariabelnya terdiri dari job satisfaction, pay satisfaction, komitmen organisasional dan turnover intention. Pada penelitian ini regression weight digunakan untuk uji hipotesis $\mathrm{H}_{1}, \mathrm{H}_{2}, \mathrm{H}_{3}, \mathrm{H}_{4}, \mathrm{H}_{5}$.

Menurut Hair et.al dalam Ferdinand (2006) terdapat 7 langkah yang harus dilakukan bila menggunakan Structural Equation Model (SEM) yaitu :

a. Pengembangan Model Teoritis 
Dalam langkah pengembangan model teoritis, hal yang harus dilakukan adalah melakukan serangkaian eksploitasi ilmiah melalui telaah pustaka guna mendapatkan justifikasi atas model teoritis yang akan dikembangkan. SEM digunakan bukan untuk menghasilkan sebuah model, tetapi digunakan untuk mengkonfirmasi model teoritis tersebut melalui data empirik.

b. Pengembangan Path Diagram

Dalam langkah kedua ini, model teoritis yang telah dibangun pada tahap pertama akan digambarkan dalam sebuah path diagram, yang akan mempermudah untuk melihat hubungan-hubungan kausalitas yang ingin diuji. Dalam path diagram, hubungan antar konstruk akan dinyatakan melalui anak panah. Anak panah yang lurus menunjukkan sebuah hubungan kausal yang langsung antara satu konstruk dengan konstruk lainnya. Sedangkan garis- garis lengkung antara konstruk dengan anak panah pada setiap ujungnya menunjukkan korelasi antara konstruk-konstruk yang dibangun dalam path diagram yang dapat dibedakan dalam dua kelompok, menurut Hair, et al (1995) dalam Ferdinand (2006) yaitu sebagai berikut :

1) Exogenous constructs yang dikenal juga sebagai independent variables yang tidak diprediksi oleh variabel yang lain dalam model. Konstruk eksogen adalah konstruk yang dituju oleh garis dengan satu ujung panah.

2) Endogenous constructs yang merupakan faktor-faktor yang diprediksi oleh satu atau beberapa konstruk. Konstruk endogen dapat memprediksi satu atau beberapa konstruk endogen lainnya, tetapi konstruk eksogen hanya dapat berhubungan kausal dengan konstruk endogen.

\section{Gambar III.1}

Diagram Alur

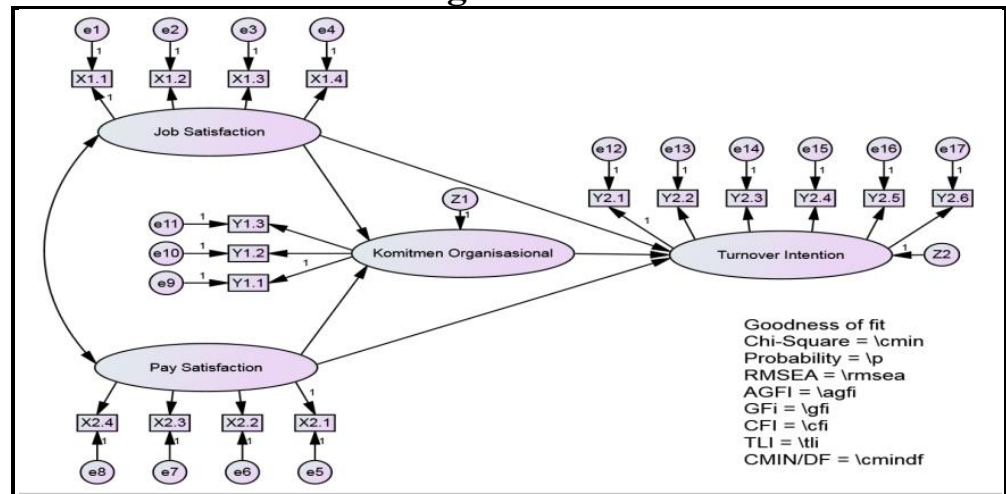

Sumber : Dikembangkan untuk penelitian ini

Keterangan

$\mathrm{X} 1.1=$ Kesempatan promosi

$\mathrm{X} 1.2=$ Rekan kerja.

$\mathrm{X} 1.3$ = Pengawasan.

$\mathrm{X} 1.4=$ Pekerjaan itu sendiri.

$\mathrm{X} 2.1=$ Economic need .

$\mathrm{X} 2.2=$ Ekuitas.

X2.3 = Organizational support .

X2.4 = Organizational support .

$\mathrm{Y} 1.1=$ Identifikasi.

Y1.2 = Keterlibatan

$\mathrm{Y} 1.3=$ Loyalitas.
Y2.1 = Pikiran untuk keluar dari

organisasi.

Y2.2 = Pikiran untuk keluar dari

organisasi.

Y2.3 = Kemungkinan untuk mencari pekerjaan baru.

Y2.4 = Kemungkinan untuk mencari pekerjaan baru.

Y2.5 = Keaktifan dalam mencari pekerjaan baru.

Y2.6 = Keaktifan dalam mencari pekerjaan baru. 
c. Konversi Path Diagram ke Dalam Persamaan

Pada langkah ini dapat mulai mengkonversi spesifikasi model kedalam rangkaian persamaan. Persamaan yang dibangun dari diagram alur yang dikonversi terdiri dari :

1) Persamaan Struktural, yang dirumuskan untuk menyatakan hubungan kausalitas, bahwa setiap konstruk endogen merupakan variabel dependen yang terpisah. Sedangkan variabel independen adalah semua konstruk yang mempunyai garis dengan anak panah yang menghubungkan ke konstruk endogen dengan pedoman sebagai berikut:

a) Komitmen organisasional $=\beta_{1}$ Job satisfaction $+\beta_{1}$ Pay satisfaction $+\mathrm{z}_{1}$

b) Turnover intention $=\beta_{1}$ Job satisfaction $+\beta_{2}$ Pay satisfaction $+\beta_{3}$ Komitmen organisasional $+\mathrm{z}_{2}$

2) Persamaan spesifikasi model pengukuran, dimana peneliti menentukan variabel yang mengukur konstruk serta menentukan serangkaian matriks yang menunjukkan kondisi yang dihipotesiskan antar konstruk atau variabel.

Model Pengukuran :

Konsep Eksogen :

$\mathrm{X} 1.1=\lambda 1.1$ Job satisfaction $+\varepsilon 1$

$\mathrm{X} 1.2=\lambda 1.2 \mathrm{Job}$ satisfaction $+\varepsilon 2$

$\mathrm{X} 1.3=\lambda 1.3 \mathrm{Job}$ satisfaction $+\varepsilon 3$

$\mathrm{X} 1.4=\lambda 1.4$ Job satisfaction $+\varepsilon 4$

$\mathrm{X} 2.1=\lambda 2.1$ Pay satisfaction $+\varepsilon 5$

$\mathrm{X} 2.2=\lambda 2.2$ Pay satisfaction $+\varepsilon 6$

$\mathrm{X} 2.3=\lambda 2.3$ Pay satisfaction $+\varepsilon 7$

$\mathrm{X} 2.4=\lambda 2.4$ Pay satisfaction $+\varepsilon 8$

Konsep Endogen :

Y1.1 $=\lambda 1.1 \quad$ Komitmen organisasional $+\varepsilon 9$

Y1.2 $=\lambda 1.2$ Komitmen
organisasional $+\varepsilon 10$
Y1.3 $=\lambda 1.3 \quad$ Komitmen
organisasional $+\varepsilon 11$
Y2.1 $=\lambda 2.1$ Turnover intention +
$\varepsilon 12$
Y2.2 $=\lambda 2.2$ Turnover intention +
$\varepsilon 13$
Y2.3 $=\lambda 2.3$ Turnover intention +
$\varepsilon 14$
Y2.4 $=\lambda 2.4$ Turnover intention +
$\varepsilon 15$
Y2.5 $=\lambda 2.5$ Turnover intention +
$\varepsilon 16$
Y2.6
$\varepsilon 17$

d. Memilih Matriks Input dan Estimasi Model

SEM menggunakan input data yang hanya menggunakan matriks varians/kovarians atau matrik korelasi untuk keseluruhan estimasi yang dilakukan. Matriks kovarian digunakan karena SEM memiliki keunggulan dalam menyajikan perbandingan yang valid antara populasi yang berbeda atau sampel yang berbeda, yang tidak dapat disajikan oleh korelasi. Hair, et al (1995) Ferdinand (2006) menganjurkan agar menggunakan matriks varians/kovarians pada saat pengujian teori sebab lebih memenuhi asumsi-asumsi metodologi dimana standard error yang dilaporkan akan menunjukkan angka yang lebih akurat dibanding menggunakan matriks korelasi. Masalah

e. Identifikasi Kemungkinan Munculnya Problem identifikasi pada prinsipnya adalah problem mengenai ketidakmampuan dari model yang dikembangkan untuk menghasilkan estimasi yang unik (terdapat lebih dari satu variabel dependen). Menurut Hair, et al (1995) Ferdinand (2006) bila setiap kali estimasi dilakukan muncul problem identifikasi, maka sebaiknya model dipertimbangkan 
ulang dengan mengembangkan lebih banyak konstruk.

f. Evaluasi Kriteria Goodness of Fit

Evaluasi terhadap kesesuaian model dilakukan melalui telaah terhadap berbagai kriteria Goodness of Fit, dengan tahapan sebagai berikut :

1) Asumsi-Asumsi SEM

Untuk mengevaluasi apakah data yang digunakan untuk dapat memenuhi asumsi asumsi SEM yang dilakukan dengan beberapa langkah :

a) Ukuran Sampel

Ukuran sampel minimum yang disarankan dalam penggunaan SEM adalah sebanyak 100-200 atau menggunakan perbandingan 5-10 kali jumlah observasi untuk setiap estimated parameter atau indikator yang dipakai Hair, et al (1995) Ferdinand (2006).

b) Normalitas dan Linearitas

Sebaran data harus dianalisis untuk melihat asumsi normalitas dipenuhi dan normalitas dapat diuji melalui gambar histogram data. Uji linearitas dapat dilakukan melalui scatterplots dari data, yaitu dengan memilih pasangan data dan dilihat pola penyebarannya untuk menduga ada tidaknya linearitas.

c) Outliers

Outliers merupakan observasi dengan nila-nilai ekstrim baik secara univariate maupun multivariate yang muncul karena kombinasi karakteristik unik yang dimilikinya dan terlihat sangat jauh berbeda dari observasi-observasi lainnya.
Singularitas

d) Multikolinearitas dan

Nilai determinan matriks kovarians yang sangat kecil memberikan indikasi adanya problem multikolinearitas atau singularitas. Perlakuan yang diupayakan adalah dengan mengeluarkan variabel yang menyebabkan multikolinearitas atau singularitas tersebut.

2) Uji Kesesuaian dan Uji Statistik Kesesuaian model dievaluasi melalui berbagai criteria goodness of fit. Berbagai indeks kesesuaian dan cut off value untuk menguji apakah sebuah model dapat diterima atau ditolak sebagai berikut Hair, et al (1995) Ferdinand (2006):

a) $\chi^{2}$-Chi square statistic

$\chi^{2}-C h i$ square statistic merupakan alat uji paling fundamental untuk mengukur overall fit. Chi square bersifat sangat sensitif terhadap besarnya sampel yang digunakan, dimana penggunaan chi square hanya sesuai bila ukuran sampel antara 100 sampai 200 sampel. Model yang diuji dipandang baik atau memuaskan bila nilai chi square-nya rendah karena dalam uji beda chi square, $\chi^{2}$ $=0$ berarti benar-benar tidak ada perbedaan. Semakin kecil nilai $\chi^{2}$ semakin baik model itu dan diterima berdasarkan probabilitas dengan cut-off value sebesar $\mathrm{p}>0,05$ atau $\mathrm{p}>0,10$ (Hulland dalam Ferdinand, 2006).

b) Probability

Nilai probability yang dapat diterima adalah $\mathrm{p}>0,05$ 
c) RMSEA (The Root Mean Square Error of Approximation)

RMSEA merupakan sebuah indeks yang dapat digunakan untuk mengkompensasi chi square dalam sampel yang besar. Nilai RMSEA menunjukkan goodness-of-fit yang dapat diharapakan bila model diestimasi dalam populasi. Nilai RMSEA yang lebih kecil atau sama dengan 0,08 merupakan indeks untuk dapat diterimanya model yang menunjukkan sebuah close fit dari model itu berdasarkan degrees of freedom (Brown \& Cudeck, 1993, dalam Ferdinand, 2006).

d) GFI (Goodness of Fit Index) Nilai indeks ini akan menghitung proporsi tertimbang dari varians dalam matriks kovarian sampel yang dijelaskan oleh matriks kovarian pupulasi yang terestimasikan. GFI adalah sebuah ukuran non statistikal yang mempunyai rentang nilai antara 0 (poor fit) sampai dengan 1,0 (perfect fit). Nilai yang tinggi dalam indeks menunjukkan sebuah "better fit". (Ferdinand, 2006).

e) AGFI (Adjusted Goodness of

Fit Index)

Dimana tingkat penerimaan yang direkomendasikan adalah bila AGFI mempunyai nilai sama dengan atau lebih besar dari 0.90 (Hulland et.al., 1996, dalam Ferdinand, 2006).

f) TLI (Tucker Lewis Index)
TLI merupakan incremental fit index yang membandingkan sebuah model yang diuji terhadap sebuah baseline model, dimana nilai yang direkomendasikan sebagai acuan untuk diterimanya sebuah model $\geq 0.95$ (Hair et.al. 1995, dalam Ferdinand, 2006) dan nilai yang mendekati 1 menunjukkan " $a$ very good fit" (Arbuckle, 1997, dalam Ferdinand, 2006).

g) CFI (Comparative Fit Index) Nilai indeks ini antara 0-1, dimana bila mendekati 1, mengindikasikan tingkat fit yang paling tinggi (Arbuckle, 1997; dalam Ferdinand, 2006). Nilai yang direkomendasikan adalah $\mathrm{CFI} \geq 0.95$.

h) $\mathrm{CMIN} / \mathrm{DF}$

CMIN/DF merupakan The Minimum Sample Discrepancy Function yang dibagi dengan degree of freedom. CMIN/DF tidak lain adalah statistik chi square. X2 dibagi DF-nya disebut $\mathrm{X} 2$ relatif. Bila nilai $\mathrm{X} 2$ relatif kurang dari 2.0 adalah indikasi dari acceptable fit antara model dan data (Arbuckle, 1997; dalam Ferdinand, 2006).

Berikut ini disajikan beberapa goodness of index kesesuaian dan cut off value untuk menguji apakah sebuah model dapat diterima atau ditolak:

Tabel

Goodness of index dan Cut-off Value 
Goodness of index

Chi square

Probability

RMSEA

GFI

AGFI

TLI

CFI

CMIN/DF
Cut-off Value

Diharapkan kecil

$$
\begin{aligned}
& \geq 0,05 \\
& \leq 0,08 \\
& \geq 0,90 \\
& \geq 0,90 \\
& \geq 0,95 \\
& \geq 0,95 \\
& \leq 2
\end{aligned}
$$

Sumber : Augusty Ferdinand (2006)

Model

g. Interpretasi dan Modifikasi

Langkah terakhir adalah menginterpretasikan model dan bagi model yang tidak memenuhi syarat pengujian dilakukan modifikasi. Pada tahap ini model diinterpretasikan dan dimodifikasi, bagi modelmodel yang tidak memenuhi syarat pengujian yang dilakukan. Hair, et al (1995) Ferdinand (2006) memberikan pedoman untuk mempertimbangkan perlu tidaknya memodifikasi sebuah model dengan melihat jumlah residual yang dihasilkan oleh model. Batas keamanan untuk jumlah residual yang dihasilkan oleh model, maka sebuah modifikasi mulai perlu dipertimbangkan. Nilai residual yang lebih besar atau sama dengan 1,96 (kurang lebih) diinterpretasikan sebagai signifikan secara statistik pada tingkat $5 \%$. 


\section{HASIL PENELITIAN}

\section{Karakteristik Responden Berdasarkan Jenis Kelamin}

Berdasarkan hasil penelitian karakteristik responden berdasarkan jenis kelamin sebagai berikut:

Tabel

Karakteristik Responden Berdasarkan Jenis Kelamin

\begin{tabular}{|c|c|c|c|}
\hline No & Jenis Kelamin & Jumlah (orang) & Prosentase (\%) \\
\hline 1. & Laki-laki & 62 & 60,78 \\
\hline 2. & Perempuan & 40 & 39,22 \\
\hline & Jumlah & $\mathbf{1 0 2}$ & $\mathbf{1 0 0}$ \\
\hline
\end{tabular}

Sumber: Data primer yang diolah

Berdasarkan tabel di atas dapat dijelaskan bahwa sebagian besar responden yang diteliti adalah laki-laki yaitu sebanyak 62 orang responden atau 60,78\% dan sisanya sebanyak 40 orang responden atau 39,22\% adalah perempuan.

\section{Karakteristik Responden Berdasarkan Umur}

Berdasarkan hasil penelitian karakteristik responden berdasarkan umur sebagai berikut:

Tabel

\section{Karakteristik Responden Berdasarkan Umur}

\begin{tabular}{|c|c|c|c|}
\hline No & Umur (tahun) & Jumlah (orang) & Prosentase (\%) \\
\hline 1. & $18-20$ & 15 & 14,70 \\
\hline 2. & $21-30$ & 61 & 59,80 \\
\hline 3. & $31-40$ & 21 & 20,60 \\
\hline 4. & $41-50$ & 5 & 4,90 \\
\hline & Jumlah & $\mathbf{1 0 2}$ & $\mathbf{1 0 0}$ \\
\hline
\end{tabular}

Sumber: Data primer yang diolah

Berdasarkan tabel di atas dapat dijelaskan bahwa karakteristik responden berdasarkan umur dari 102 responden terdapat 15 orang responden, umur antara 18 sampai 20 tahun, 61 orang responden, mempunyai umur antara 21 sampai dengan 30,21 orang responden, mempunyai umur antara 31 sampai dengan 40 dan 5 orang responden, mempunyai umur antara 41 sampai dengan 50 .

\section{Karakteristik Responden Berdasarkan Lama Kerja}

Berdasarkan hasil penelitian karakteristik responden berdasarkan lama kerja sebagai berikut:

Tabel

Karakteristik Responden Berdasarkan Lama Kerja

\begin{tabular}{|c|c|c|c|}
\hline No & Lama Kerja (tahun) & Jumlah (orang) & Prosentase (\%) \\
\hline 1. & $1-2$ & 41 & 40,19 \\
\hline 2. & $2-3$ & 32 & 31,37 \\
\hline 3. & $3-4$ & 11 & 12,74 \\
\hline 4. & $4-5$ & 10 & 9,80 \\
\hline 5. & $>5$ & 6 & 5,90 \\
\hline & Jumlah & $\mathbf{1 0 2}$ & $\mathbf{1 0 0}$ \\
\hline
\end{tabular}

Sumber: Data primer yang diolah 
Berdasarkan tabel di atas dapat dijelaskan bahwa karakteristik responden berdasarkan lama kerja dari 102 responden terdapat 41 orang responden atau 40,19\% mempunyai lama kerja antara 1 sampai dengan 2 tahun, terdapat 32 orang responden atau 31,37\% mempunyai lama kerja antara 2 sampai dengan 3 tahun, terdapat 11 orang responden atau $12,74 \%$ mempunyai lama kerja antara 3 sampai dengan 4 tahun, terdapat 10 orang responden atau 9,80\% mempunyai lama kerja antara 4 sampai dengan 5 tahun dan 6 orang responden atau 5,90\% mempunyai lama kerja lebih dari 5 tahun.

\section{Karakteristik Responden Berdasarkan Tingkat Pendidikan}

Berdasarkan hasil penelitian karakteristik responden berdasarkan tingkat pendidikan sebagai berikut :

Tabel

Karakteristik Responden Berdasarkan Tingkat Pendidikan

\begin{tabular}{|c|l|c|c|}
\hline No & Tingkat Pendidikan & Jumlah (orang) & Prosentase (\%) \\
\hline 1. & SD & 2 & 1,96 \\
\hline 2. & SMP & 16 & 15,70 \\
\hline 3. & SMA & 71 & 69,60 \\
\hline 4. & D3 & 9 & 8,82 \\
\hline 5. & S1 & 4 & 3,92 \\
\hline 6. & Lainnya & - & - \\
\hline & Jumlah & $\mathbf{1 0 2}$ & $\mathbf{1 0 0}$ \\
\hline
\end{tabular}

Sumber: Data primer yang diolah,

Berdasarkan tabel di atas dapat dijelaskan bahwa karakteristik responden berdasarkan tingkat pendidikan dari 102 responden terdapat terdapat 2 orang responden atau 1,96\% yang berpendidikan SD, terdapat terdapat 16 orang responden atau $15,70 \%$ yang berpendidikan SMP, terdapat terdapat 71 orang responden atau 69,60\% yang berpendidikan SMA, terdapat terdapat 9 orang responden atau $8,82 \%$ yang berpendidikan D3, terdapat 4 orang responden atau 3,92\% yang berpendidikan S1 dan lainnya berjumlah 0 .

\section{Analisis kuantitatif}

1. Uji Validitas Job Satisfaction (Kepuasan Kerja)

Uji validitas variabel job satisfaction (kepuasan kerja) penulis sajikan dalam bentuk tabel sebagai berikut:

Tabel

Hasil Uji Validitas Job Satisfaction (Kepuasan Kerja)

\begin{tabular}{|c|c|c|c|c|}
\hline Item & Nilai $\mathbf{r}$ hitung & Nilai $\mathbf{r}$ tabel & Sig & Keterangan \\
\hline 01 & 0,692 & 0,195 & 0,000 & Valid \\
\hline 02 & 0,704 & 0,195 & 0,000 & Valid \\
\hline 03 & 0,720 & 0,195 & 0,000 & Valid \\
\hline 04 & 0,690 & 0,195 & 0,000 & Valid \\
\hline
\end{tabular}

Sumber : Data primer yang diolah

Tabel di atas menunjukkan bahwa seluruh item pernyataan yang digunakan untuk mengukur variabel job satisfaction (kepuasan kerja) dinyatakan valid atau sah, karena diperoleh angka $r$ hitung secara keseluruhan mempunyai nilai lebih besar dari nilai $r$ tabel yaitu lebih besar dari 0,195 . 
2. Uji Validitas Pay Satisfaction (Kepuasan Gaji)

Uji validitas variabel pay satisfaction (Kepuasan Gaji) penulis sajikan dalam bentuk tabel sebagai berikut:

Tabel

Hasil Uji Validitas Pay Satisfaction (Kepuasan Gaji)

\begin{tabular}{|c|c|c|c|c|}
\hline Item & Nilai $\mathbf{r}_{\text {hitung }}$ & Nilai $\mathbf{r}$ tabel & Sig & Keterangan \\
\hline 01 & 0,664 & 0,195 & 0,000 & Valid \\
\hline 02 & 0,736 & 0,195 & 0,000 & Valid \\
\hline 03 & 0,753 & 0,195 & 0,000 & Valid \\
\hline 04 & 0,730 & 0,195 & 0,000 & Valid \\
\hline
\end{tabular}

Sumber : Data primer yang diolah

Tabel di atas menunjukkan bahwa seluruh item pernyataan yang digunakan untuk mengukur variabel pay satisfaction (kepuasan gaji) dinyatakan valid atau sah, karena diperoleh angka $r$ hitung secara keseluruhan mempunyai nilai lebih besar dari nilai $r$ tabel yaitu lebih besar dari $0,195$.

3. Uji Validitas Komitmen Organisasional

Uji validitas variabel komitmen organisasional penulis sajikan dalam bentuk tabel sebagai berikut :

Tabel

Hasil Uji Validitas Komitmen Organisasional

\begin{tabular}{|c|c|c|c|c|}
\hline Item & Nilai $\mathbf{r}_{\text {hitung }}$ & Nilai $\mathbf{r}_{\text {tabel }}$ & Sig & Keterangan \\
\hline 01 & 0,753 & 0,195 & 0,000 & Valid \\
\hline 02 & 0,855 & 0,195 & 0,000 & Valid \\
\hline 03 & 0,808 & 0,195 & 0,000 & Valid \\
\hline
\end{tabular}

Sumber : Data primer yang diolah

Tabel diatas menunjukkan bahwa seluruh item pernyataan yang digunakan untuk mengukur variabel komitmen organisasional dinyatakan valid atau sah, karena diperoleh angka $r$ hitung secara keseluruhan mempunyai nilai lebih besar dari nilai $r$ tabel yaitu lebih besar dari 0,195 .

4. Uji Validitas Turnover Intention (Niat Untuk Pindah Kerja)

Uji validitas variabel turnover intention (niat untuk pindah kerja) penulis sajikan dalam bentuk tabel sebagai berikut:

Tabel

Hasil Uji Validitas Turnover Intention (Niat Untuk Pindah Kerja)

\begin{tabular}{|c|c|c|c|c|}
\hline Item & Nilai $\mathbf{r}_{\text {hitung }}$ & Nilai $\mathbf{r}$ tabel & Sig & Keterangan \\
\hline 01 & 0,698 & 0,195 & 0,000 & Valid \\
\hline 02 & 0,701 & 0,195 & 0,000 & Valid \\
\hline 03 & 0,608 & 0,195 & 0,000 & Valid \\
\hline 04 & 0,705 & 0,195 & 0,000 & Valid \\
\hline 05 & 0,584 & 0,195 & 0,000 & Valid \\
\hline 06 & 0,531 & 0,195 & 0,000 & Valid \\
\hline
\end{tabular}

Sumber : Data primer yang diolah

Tabel di atas menunjukkan bahwa seluruh item pernyataan yang digunakan untuk mengukur variabel turnover intention (niat untuk pindah kerja) dinyatakan valid atau sah, karena diperoleh angka $r$ hitung secara keseluruhan mempunyai nilai lebih besar dari nilai $r$ tabel yaitu lebih besar dari 0,195. 
Tabel

Hasil Uji Reliabilitas Kuesioner

\begin{tabular}{|c|l|c|c|}
\hline No & \multicolumn{1}{|c|}{ Item pertanyaan/pernyataan } & $\begin{array}{c}\text { Cronbach } \\
\text { alpha }\end{array}$ & Ket. \\
\hline 1. & Job satisfaction (kepuasan kerja). & 0,666 & Reliabel \\
\hline 2. & Pay satisfaction (kepuasan gaji). & 0,694 & Reliabel \\
\hline 3. & Komitmen organisasional. & 0,729 & Reliabel \\
\hline 4. & $\begin{array}{l}\text { Turnover intention (niat untuk } \\
\text { pindah kerja). }\end{array}$ & 0,711 & Reliabel \\
\hline
\end{tabular}

Sumber : Data primer yang diolah

Berdasarkan tabel di atas dapat dilihat bahwa nilai cronbach alpha untuk variabel job satisfaction sebesar 0,666, untuk variabel pay satisfaction sebesar 0,694, untuk variabel komitmen organisasional sebesar 0,729 dan variabel turnover intention sebesar 0,711. Hasil uji reliabilitas tersebut menunjukkan bahwa semua variabel mempunyai koefisien Alpha yang cukup besar yaitu di atas 0,60 sehingga dapat dikatakan semua konsep pengukur masingmasing variabel dari kuesioner adalah reliabel.

\section{Uji Normalitas}

Analisis terhadap hasil uji normalitas pada penelitian ini dengan menggunakan bantuan programisasi komputer dengan program AMOS 21.0 for Windows Untuk mengevaluasi kenormalitasan data, dilakukan dengan mengamati nilai CR multivariate dengan rentang \pm 2.58 pada tingkat signifikansi 1\%. Adapun hasil uji normalitas disajikan dalam tabel berikut ini :

\section{Tabel}

Hasil Uji Normalitas Data

\begin{tabular}{|c|c|c|c|c|c|c|}
\hline Variable & $\min$ & $\max$ & skew & c.r. & kurtosis & c.r. \\
\hline Y2.6 & 1,000 & 4,000 &, 748 & 3,086 &,- 288 &,- 594 \\
\hline Y2.5 & 1,000 & 4,000 & 1,097 & 4,524 & 1,358 & 2,799 \\
\hline Y2.4 & 1,000 & 4,000 &,- 346 & $-1,427$ & $-1,033$ & $-2,129$ \\
\hline Y2.3 & 1,000 & 4,000 &,- 719 & $-2,965$ & $-1,019$ & $-2,100$ \\
\hline Y2.2 & 1,000 & 4,000 & $-1,003$ & $-4,137$ &,- 054 &,- 112 \\
\hline Y2.1 & 1,000 & 4,000 &, 009 &, 038 &,- 622 & $-1,283$ \\
\hline Y1.3 & 1,000 & 4,000 &, 000 &, 000 &,- 543 & $-1,118$ \\
\hline Y1.2 & 2,000 & 4,000 &, 573 & 2,361 &,- 846 & $-1,743$ \\
\hline Y1.1 & 1,000 & 4,000 &,- 195 &,- 804 &,- 662 & $-1,365$ \\
\hline X2.4 & 1,000 & 4,000 &,- 356 & $-1,468$ & $-1,220$ & $-2,516$ \\
\hline X2.3 & 1,000 & 4,000 &,- 440 & $-1,815$ & $-1,145$ & $-2,361$ \\
\hline X2.2 & 1,000 & 4,000 &,- 675 & $-2,785$ &,- 093 &,- 192 \\
\hline X2.1 & 1,000 & 4,000 &,- 918 & $-3,783$ &,- 503 & $-1,037$ \\
\hline X1.4 & 1,000 & 4,000 &,- 127 &,- 524 & $-1,890$ & $-3,897$ \\
\hline X1.3 & 1,000 & 4,000 &,- 164 &,- 675 & $-1,283$ & $-2,644$ \\
\hline X1.2 & 1,000 & 4,000 &,- 791 & $-3,261$ &,- 603 & $-1,243$ \\
\hline X1.1 & 1,000 & 4,000 & $-1,101$ & $-4,540$ &, 031 &, 064 \\
\hline Multivari & & & & & 3,934 &, 782 \\
\hline ate & & & & & & \\
\hline
\end{tabular}

Sumber : Data primer yang diolah 
Dari hasil pengolahan data yang ditampilkan pada table di atas terlihat bahwa hasil pengujian normalitas menunjukkan bahwa nilai CR untuk multivariate adalah 0,782 . Dengan demikian maka data penelitian yang digunakan telah memenuhi persyaratan normalitas data atau dapat dikatakan bahwa data penelitian telah terdistribusi normal.

\section{Outliers}

Dengan menggunakan observasi yang mempunyai Zs core $\geq \pm 3$ akan dikateogrikan sebagai univariate outlier. Berdasarkan hasil nilai z score menggunakan program SPSS 22.0 for windows, diperoleh data seperti pada tabel berikut ini :

Tabel

Hasil Uji Univariate Outliers

\begin{tabular}{|l|c|r|r|r|r|}
\hline \multicolumn{7}{|c|}{ Descriptive Statistics } \\
\hline & $\mathrm{N}$ & Minimum & Maximum & Mean & $\begin{array}{c}\text { Std. } \\
\text { Deviation }\end{array}$ \\
\hline Zscore(X1.1) & 102 & $-2,47929$ &, 73538 &, 0000000 & 1,00000000 \\
\hline Zscore(X1.2) & 102 & $-2,17090$ &, 86241 &, 0000000 & 1,00000000 \\
\hline Zscore(X1.3) & 102 & $-1,63279$ & 1,17414 &, 0000000 & 1,00000000 \\
\hline Zscore(X1.4) & 102 & $-1,11755$ &, 98043 &, 0000000 & 1,00000000 \\
\hline Zscore(X2.1) & 102 & $-2,32047$ &, 76677 &, 0000000 & 1,00000000 \\
\hline Zscore(X2.2) & 102 & $-2,60540$ & 1,06857 &, 0000000 & 1,00000000 \\
\hline Zscore(X2.3) & 102 & $-1,62753$ & 1,07913 &, 0000000 & 1,00000000 \\
\hline Zscore(X2.4) & 102 & $-1,68078$ & 1,06959 &, 0000000 & 1,00000000 \\
\hline Zscore(Y1.1) & 102 & $-2,39777$ & 1,36489 &, 0000000 & 1,00000000 \\
\hline Zscore(Y1.2) & 102 &,- 94126 & 1,88251 &, 0000000 & 1,00000000 \\
\hline Zscore(Y1.3) & 102 & $-1,80825$ & 1,80825 &, 0000000 & 1,00000000 \\
\hline Zscore(Y2.1) & 102 & $-1,83172$ & 1,69348 &, 0000000 & 1,00000000 \\
\hline Zscore(Y2.2) & 102 & $-2,14707$ &, 86671 &, 0000000 & 1,00000000 \\
\hline Zscore(Y2.3) & 102 & $-1,95714$ &, 80270 &, 0000000 & 1,00000000 \\
\hline Zscore(Y2.4) & 102 & $-1,80525$ & 1,14880 &, 0000000 & 1,00000000 \\
\hline Zscore(Y2.5) & 102 & $-1,63053$ & 2,49296 &, 0000000 & 1,00000000 \\
\hline Zscore(Y2.6) & 102 & $-1,29957$ & 1,88178 &, 0000000 & 1,00000000 \\
\hline $\begin{array}{l}\text { Valid N } \\
\text { (listwise) }\end{array}$ & 102 & & & & \\
\hline \multicolumn{2}{|c|}{ Sumber : Da prime } & & & & \\
\hline
\end{tabular}

Sumber : Data primer yang diolah

Dari Z score (X1.1) sampai dengan Z score (Y2.6) pada tabel di atas, pada kolom minimum angka yang terkecil terletak pada $Z$ score (X2.2) yaitu $-2,60540$ artinya masih lebih kecil -3 . Sedangkan pada kolom maksimum angka yang terbesar terletak pada Z score (Y2.5) yaitu 2,49296 artinya masih lebih kecil dari +3 . Oleh karena itu dari hasil pengolahan data tidak ditemukan adanya Outlier Univariate.

Untuk mendeteksi masalah outlier ini juga bisa dilakukan dengan memperhatikan nilai mahalanobis distance, kriteria yang digunakan adalah nilai Chi-square pada derajat kebebasan $(d f) 17$ yaitu jumlah variabel indikator pada signifikasi $\mathrm{p}<0,001$. Nilai mahalanobis distance $(17,0,001)=40,79$. Hal ini berarti semua kasus yang mempunyai nilai mahalanobis distance lebih besar dari 40,79 adalah multivariate outlier. Berikut ini nilai dari mahalanobis distance dengan program AMOS 21.0 for Windows, diperoleh data seperti pada tabel berikut ini : 
Tabel

Hasil Uji Mahalanobis Distance

\begin{tabular}{|c|c|c|c|}
\hline Observation number & Mahalanobis d-squared & p1 & p2 \\
\hline 46 & 30,888 &, 021 &, 880 \\
\hline 48 & 30,120 &, 025 &, 737 \\
\hline 60 & 28,988 &, 035 &, 690 \\
\hline 78 & 28,988 &, 035 &, 472 \\
\hline 23 & 28,187 &, 043 &, 444 \\
\hline 61 & 25,987 &, 075 &, 782 \\
\hline 79 & 25,987 &, 075 &, 646 \\
\hline 80 & 25,854 &, 077 &, 534 \\
\hline- & - & - & - \\
\hline- & - & - & - \\
\hline
\end{tabular}

Sumber : Data primer yang diolah

Berdasarkan tabel di atas dapat diketahui bahwa jarak mahalanobis maksimal adalah 30,888, yang masih berada di bawah batas maksimal multivariate outlier sehinngga tidak terdapat nilai mahalanobis distance yang melebihi nilai batas maka dapat disimpulkan tidak ada masalah multivariate outlier.

\section{Multikolineritas dan Singularitas}

Pengujian data selanjutnya adalah untuk melihat apakah terdapat multikolinearitas dan singularitas dalam sebuah kombinasi variabel. Indikasi adanya multikolinearitas dan singularitas dapat diketahui melalui nilai determinan matriks kovarians yang benar-benar kecil, atau mendekati nol. Dari hasil pengolahan data nilai determinan matriks kovarians sampel adalah : Determinant of sample covariance matrix $=0.000$. Dari hasil pengolahan data tersebut dapat diketahui nilai determinant of sample covariance matrix berada pada nol. sehingga dapat disimpulkan bahwa terdapat multikolinearitas atau singularitas dalam model, adanya masalah multikolinearitas dalam model ini dianggap wajar, karena menurut (Setiaji, 2006) menyebutkan bahwa model-model dengan variabel interaksi, umumnya mengandung masalah kolinearitas yang tinggi.

\section{Uji kesalahan spesifikasi model}

Interpretasi dan modifikasi dimaksudkan untuk melihat apakah model yang dikembangkan dalam penelitian ini, perlu dimodifikasi atau dirubah sehingga mendapatkan model yang lebih baik lagi. Sebuah model penelitian dikatakan baik jika memiliki nilai Standardized Residual Covarian yang didalam standar yang ditetapkan $(\leq \pm 2,58)$. Hasil Standardized Residual Covarian model penelitian ini ditampilkan pada lampiran.

Hasil analisis statistik yang dilakukan dalam penelitian ini, ditemukan enam nilai standardized residual kovarians yang lebih dari \pm 2.58 namun demikian, jumlahnya tidak melebihi $5 \%$ dari semua residual kovarians yang dihasilkan oleh model sehingga dapat dikatakan bahwa syarat residual terpenuhi (Ferdinand, 2006).

\section{Analisis Faktor Konfirmatori (Confirmatory Faktor Analysis)}

Analisis faktor konfirmatori bertujuan untuk menguji unidimensionalitas dari dimensi-dimensi pembentuk masing-masing variabel laten. Hasil analisis faktor konfirmatori dari masingmasing model selanjutnya akan dibahas seperti tabel berikut ini : 
1. Analisis Faktor Konfirmatori - Job Satisfaction

Gambar

Analisis Faktor Konfirmatori Job Satisfaction

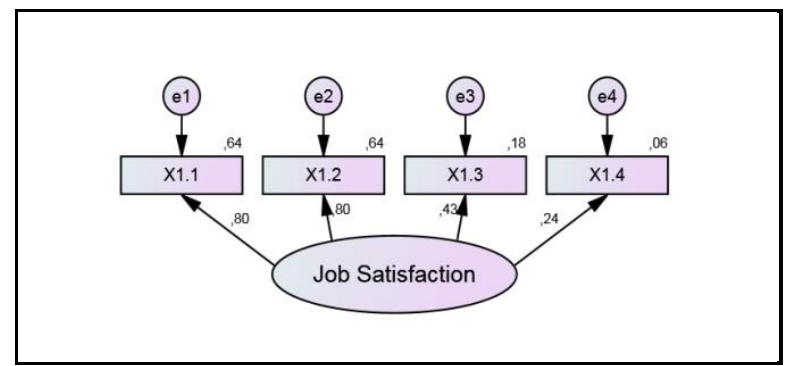

Sumber : Data primer yang diolah

2. Analisis Faktor Konfirmatori - Pay Satisfaction

Gambar

Analisis Faktor Konfirmatori Pay Satisfaction

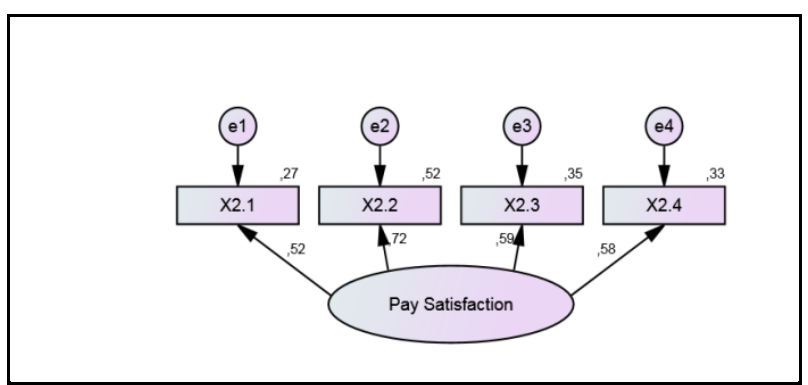

Sumber : Data primer yang diolah

3. Analisis Faktor Konfirmatori - Komitmen Organisasional

Gambar

Analisis Faktor Konfirmatori Komitmen Organisasional

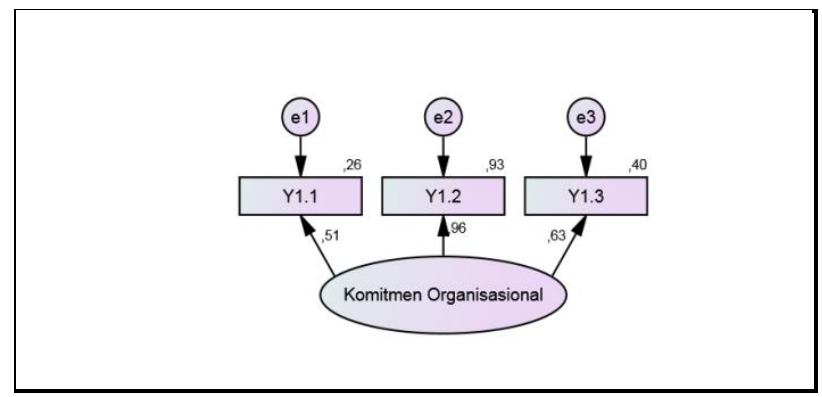

Sumber : Data primer yang diolah

4. Analisis Faktor Konfirmatori - Turnover Intention

Gambar

Analisis Faktor Konfirmatori Turnover Intention

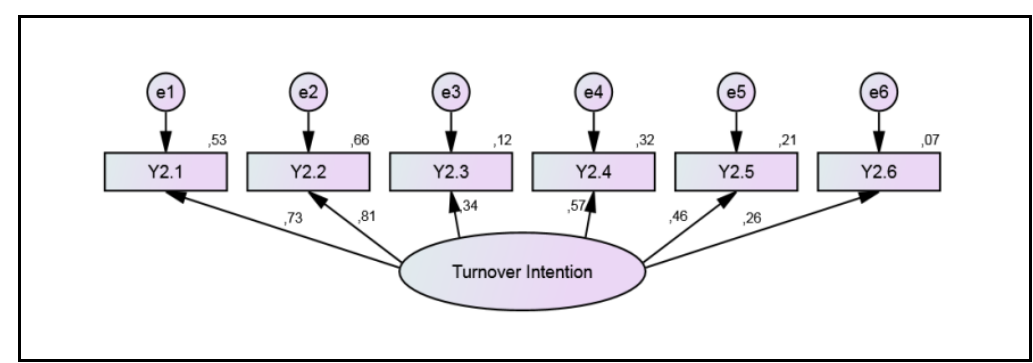

Sumber : Data primer yang diolah 
Hasil analisis pengolahan data terlihat bahwa konstruk yang digunakan untuk membentuk sebuah model penelitian, pada proses analisis faktor konfirmatori telah memenuhi kriteria goodness of fit yang telah ditetapkan.

\section{Analisis Structural Equation Modeling (SEM)}

Analisis structural equation modeling digunakan untuk mengetahui hubungan struktural antar variabel yang diteliti. Hubungan struktural antar variabelnya dilihat dari diagram jalur yang diperoleh dari output program AMOS 21.0 for Windows dan diuji kesesuaiannya menggunakan goodness-of-fit index. Hasil diagram jalur hubungan antara job satisfaction, pay satisfacton, komitmen organisasional dan turnover intention sebagai berikut:

\section{Gambar}

\section{Hasil Analisis Full SEM}

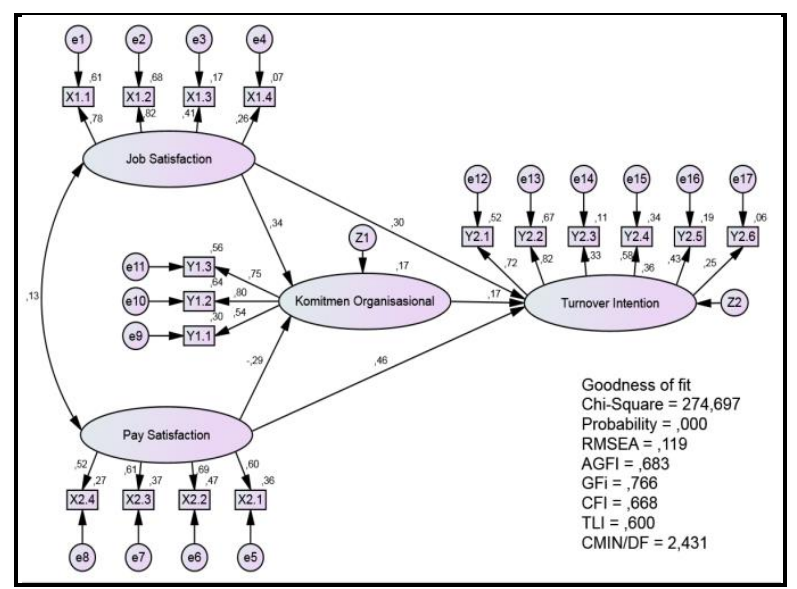

Sumber : Data primer yang diolah

Model struktural hubungan variabel job satisfaction, pay satisfaction, komitmen organisasional dan turnover intention diuji kecocokannya menggunakan Goodness of index seperti tampak pada tabel berikut ini :

Tabel

Hasil Uji Model Goodness-of-fit test Analisis SEM

\begin{tabular}{|c|c|c|c|}
\hline Goodness of index & Cut-off Value & Hasil model & Keterangan \\
\hline Chi square & 138,811 & 274,697 & Kurang Baik \\
\hline Probability & $\geq 0,05$ & 0,000 & Kurang Baik \\
\hline RMSEA & $\leq 0,08$ & 0,119 & Kurang Baik \\
\hline GFI & $\geq 0,90$ & 0,766 & Kurang Baik \\
\hline AGFI & $\geq 0,90$ & 0,683 & Kurang Baik \\
\hline TLI & $\geq 0,95$ & 0,600 & Kurang Baik \\
\hline CFI & $\geq 0,95$ & 0,668 & Kurang Baik \\
\hline CMIN/DF & $<2$ & 2,431 & Kurang Baik \\
\hline
\end{tabular}

Sumber: Data primer yang diolah 
Dari tabel di atas menunjukkan bahwa model yang digunakan belum menunjukkan sebagai suatu model persamaan struktural yang baik. Karena nilai Chi square, Probability, RMSEA, GFI, AGFI, TLI, CFI, dan CMIN/DF diterima secara kurang baik. Dengan demikian uji kelayakan model SEM belum memenuhi syarat penerimaan. Akan tetapi dikarenakan keterbatasan data dan waktu untuk melakukan penelitian lagi maka uji model goodness-of-fit test analisis SEM tersebut tetap dilanjutkan untuk diteliti.

Uji Hipotesis

Untuk melakukan pengujian terhadap hipotesis yang diajukan dilakukan dengan menganalisis regression weights. Dengan melihat nilai C.R yang identik dengan $t_{\text {hitung, }}$, pada hasil pengolahan dibandingkan dengan nila $t_{\text {tabel }}$ yang diproksikan dengan nilai $\pm 1,96$ pada tingkat signifkansi 0,05. Apabila nilai C.R $>1,96$, maka dapat disimpulkan hubungan kausal antara variabel tersebut signifikan. Hasil analisis regression weight menggunakan program AMOS 21.0 for Windows, dapat disajikan pada tabel berikut ini :

\section{Tabel}

Hasil Uji Regression Weights

\begin{tabular}{|c|c|c|c|c|c|c|c|}
\hline & & $\begin{array}{c}\text { Esti } \\
\text { mate }\end{array}$ & S.E. & C.R. & P & Label \\
\hline $\begin{array}{c}\text { Komitmen } \\
\text { Organisasio } \\
\text { nal }\end{array}$ & $\leftarrow$ & $\begin{array}{c}\text { Job } \\
\text { Satisfaction }\end{array}$ &, 202 &, 096 & 2,110 &, 035 & par_14 \\
\hline $\begin{array}{c}\text { Komitmen } \\
\text { Organisasio } \\
\text { nal }\end{array}$ & $\leftarrow$ & $\begin{array}{c}\text { Pay } \\
\text { Satisfaction }\end{array}$ &,- 219 &, 106 & $-2,056$ &, 040 & par_15 \\
\hline $\begin{array}{c}\text { Turnover } \\
\text { Intention }\end{array}$ & $\leftarrow$ & $\begin{array}{c}\text { Job } \\
\text { Satisfaction }\end{array}$ &, 252 &, 120 & 2,097 &, 036 & par_19 \\
\hline $\begin{array}{c}\text { Turnover } \\
\text { Intention }\end{array}$ & $\leftarrow$ & $\begin{array}{c}\text { Pay } \\
\text { Satisfaction }\end{array}$ &, 483 &, 162 & 2,984 &, 003 & par_18 \\
\hline $\begin{array}{c}\text { Turnover } \\
\text { Intention }\end{array}$ & $\leftarrow$ & $\begin{array}{c}\text { Komitmen } \\
\text { Organisasio } \\
\text { nal }\end{array}$ &, 244 &, 221 & 1,103 &, 270 & par_16 \\
\hline
\end{tabular}

Sumber : Data primer yang diolah

\section{Uji Hipotesis 1}

Parameter estimasi untuk pengujian pengaruh job satisfaction terhadap komitmen organisasional menunjukkan nilai CR sebesar 2,110 dan dengan probabilitas sebesar 0,035. Kedua nilai tersebut diperoleh memenuhi syarat untuk penerimaan $\mathrm{H} 1$ yaitu nilai CR sebesar positif 2,110 yang lebih besar dari $\pm 1,96$ dan probabilitas yang lebih kecil dari 0,05 . Dengan demikian dapat disimpulkan bahwa hipotesis 1 (H1) menyatakan bahwa job satisfaction berpengaruh terhadap komitmen organisasional dan hipotesis diterima karena signifikan.

\section{Uji Hipotesis 2}

Parameter estimasi untuk pengujian pengaruh pay satisfaction terhadap komitmen organisasional menunjukkan nilai CR sebesar -2,056 dan dengan probabilitas sebesar 0,040. Kedua nilai tersebut diperoleh memenuhi syarat untuk penerimaan $\mathrm{H} 2$ yaitu nilai CR sebesar negatif 2,056 yang lebih besar dari $\pm 1,96$ dan probabilitas yang lebih kecil dari 0,05. Dengan demikian dapat disimpulkan bahwa hipotesis $2(\mathrm{H} 2)$ menyatakan bahwa pay satisfaction berpengaruh terhadap komitmen organisasional dan hipotesis diterima karena signifikan. 


\section{Uji Hipotesis 3}

Parameter estimasi untuk pengujian pengaruh job satisfaction terhadap turnover intention menunjukkan nilai CR sebesar 2,097 dan dengan probabilitas sebesar 0,036. Kedua nilai tersebut diperoleh memenuhi syarat untuk penerimaan $\mathrm{H} 3$ yaitu nilai CR sebesar positif 2,097 yang lebih besar dari $\pm 1,96$ dan probabilitas yang lebih kecil dari 0,05 . Dengan demikian dapat disimpulkan bahwa hipotesis 3 (H3) menyatakan bahwa job satisfaction berpengaruh terhadap turnover intention dan hipotesis diterima karena signifikan.

\section{Uji Hipotesis 4}

Parameter estimasi untuk pengujian pengaruh pay satisfaction terhadap turnover intention menunjukkan nilai CR sebesar 2,984 dan dengan probabilitas sebesar 0,003. Kedua nilai tersebut diperoleh memenuhi syarat untuk penerimaan $\mathrm{H} 4$ yaitu nilai CR sebesar positif 2,984 yang lebih besar dari $\pm 1,96$ dan probabilitas yang lebih kecil dari 0,05. Dengan demikian dapat disimpulkan bahwa hipotesis 4 (H4) menyatakan bahwa pay satisfaction berpengaruh terhadap turnover intention dan hipotesis diterima karena signifikan.

\section{Uji Hipotesis 5}

Parameter estimasi untuk pengujian pengaruh komitmen organisasional terhadap turnover intention menunjukkan nilai CR sebesar 1,103 dan dengan probabilitas sebesar 0,270. Kedua nilai tersebut diperoleh tidak memenuhi syarat untuk penerimaan $\mathrm{H} 5$ yaitu nilai CR sebesar positif 1,103 yang lebih kecil dari $\pm 1,96$ dan probabilitas yang lebih besar dari 0,05. Dengan demikian dapat disimpulkan bahwa hipotesis 5 (H5) menyatakan bahwa komitmen organisasional tidak berpengaruh terhadap turnover intention dan hipotesis ditolak karena tidak signifikan.

Berdasarkan hasil analisis regression weight di atas dapat dirangkum pada tabel berikut ini :

\section{Tabel}

Hasil Pengujian Hipotesis

\begin{tabular}{|c|l|c|}
\hline No. & \multicolumn{1}{|c|}{ Hipotesis } & Kesimpulan \\
\hline 1. & $\begin{array}{l}\text { Job satisfaction berpengaruh terhadap } \\
\text { komitmen organisasional. }\end{array}$ & Diterima \\
\hline 2. & $\begin{array}{l}\text { Pay satisfaction berpengaruh terhadap } \\
\text { komitmen organisasional. }\end{array}$ & Diterima \\
\hline 3. & $\begin{array}{l}\text { Job satisfaction berpengaruh terhadap turnover } \\
\text { intention. }\end{array}$ & Diterima \\
\hline 4. & $\begin{array}{l}\text { Pay satisfaction berpengaruh terhadap turnover } \\
\text { intention. }\end{array}$ & Diterima \\
\hline 5. & $\begin{array}{l}\text { Komitmen organisasional berpengaruh terhadap } \\
\text { turnover intention. }\end{array}$ & Ditolak \\
\hline
\end{tabular}

\section{Analisis Pengaruh}

Sumber : Data primer yang diolah

Analisis pengaruh dilakukan untuk menganalisis kekuatan pengaruh antar konstruk baik pengaruh yang langsung, tidak langsung, dan pengaruh totalnya. Efek langsung (direct effect) tidak lain adalah koefisien dari semua garis koefisien dengan anak panah satu ujung. Efek tidak langsung (indirect effect) adalah efek yang muncul melalui sebuah variabel antara. Efek total (total effect) adalah efek dari berbagai hubungan (Ferdinand, 2006). Hasil pengujian pengaruh langsung, tidak langsung dan total tersebut dapat menggunakan program AMOS 21.0 for Windows, dapat disajikan pada tabel berikut ini : 
Tabel

Hasil Uji Pengaruh Langsung

\begin{tabular}{|c|c|c|c|c|}
\hline & $\begin{array}{c}\text { Pay } \\
\text { Satisfaction }\end{array}$ & $\begin{array}{c}\text { Job } \\
\text { Satisfaction }\end{array}$ & $\begin{array}{c}\text { Komitmen } \\
\text { Organisasional }\end{array}$ & $\begin{array}{c}\text { Turnover } \\
\text { Intention }\end{array}$ \\
\hline $\begin{array}{c}\text { Komitmen } \\
\text { Organisasional }\end{array}$ &,- 293 &, 338 &, 000 &, 000 \\
\hline $\begin{array}{c}\text { Turnover } \\
\text { Intention }\end{array}$ &, 456 &, 299 &, 172 &, 000 \\
\hline
\end{tabular}

Sumber : Data primer yang diolah

Dari hasil perhitungan terlihat diatas bahwa job satisfaction dan pay satisfaction mempunyai pengaruh langsung terhadap komitmen organisasional masing-masing sebesar 0,338 dan 0,293. Sedangkan job satisfaction berpengaruh langsung sebesar 0,299, pay satisfaction sebesar 0,456 dan komitmen organisasional sebesar 0,172 terhadap turnover intention.

Tabel

Hasil Uji Pengaruh Tidak Langsung

\begin{tabular}{|c|c|c|c|c|}
\hline & $\begin{array}{c}\text { Pay } \\
\text { Satisfaction }\end{array}$ & $\begin{array}{c}\text { Job } \\
\text { Satisfaction }\end{array}$ & $\begin{array}{c}\text { Komitmen } \\
\text { Organisasional }\end{array}$ & $\begin{array}{c}\text { Turnover } \\
\text { Intention }\end{array}$ \\
\hline $\begin{array}{c}\text { Komitmen } \\
\text { Organisasional }\end{array}$ &, 000 &, 000 &, 000 &, 000 \\
\hline $\begin{array}{c}\text { Turnover } \\
\text { Intention }\end{array}$ &,- 050 &, 058 &, 000 &, 000 \\
\hline
\end{tabular}

Sumber : Data primer yang diolah

Dari hasil perhitungan diatas terlihat bahwa, job satisfaction mempunyai pengaruh tidak langsung terhadap komitmen organisasional dan turnover intention sebesar 0,058 sedangkan pay satisfaction mempunyai pengaruh tidak langsung terhadap komitmen organisasional dan turnover intention sebesar $-0,050$.

Tabel

Hasil Uji Pengaruh Total

\begin{tabular}{|c|c|c|c|c|}
\hline & $\begin{array}{c}\text { Pay } \\
\text { Satisfaction }\end{array}$ & $\begin{array}{c}\text { Job } \\
\text { Satisfaction }\end{array}$ & $\begin{array}{c}\text { Komitmen } \\
\text { Organisasional }\end{array}$ & $\begin{array}{c}\text { Turnover } \\
\text { Intention }\end{array}$ \\
\hline $\begin{array}{c}\text { Komitmen } \\
\text { Organisasional }\end{array}$ &,- 293 &, 338 &, 000 &, 000 \\
\hline $\begin{array}{c}\text { Turnover } \\
\text { Intention }\end{array}$ &, 406 &, 357 &, 172 &, 000 \\
\hline
\end{tabular}

Sumber : Data primer yang diolah

Dari hasil perhitungan terlihat diatas bahwa job satisfaction dan pay satisfaction mempunyai pengaruh langsung terhadap komitmen organisasional masing-masing sebesar 0,338 dan 0,293 . Sedangkan job satisfaction berpengaruh langsung sebesar 0,357 , pay satisfaction sebesar 0,406 dan komitmen organisasional sebesar 0,172 terhadap turnover intention. 


\section{Pembahasan Dan Implikasi Manajerial}

Pembahasan dan hasil dari penelitian ini adalah :

1. $\mathrm{H}_{1}:$ Job satisfaction berpengaruh terhadap komitmen organisasional karyawan Bale Group Kebumen.

Parameter estimasi untuk pengujian pengaruh job satisfaction terhadap komitmen organisasional menunjukkan nilai CR sebesar 2,110 dan dengan probabilitas sebesar 0,035. Kedua nilai tersebut diperoleh memenuhi syarat untuk penerimaan $\mathrm{H} 1$ yaitu nilai CR sebesar positif 2,110 yang lebih besar dari $\pm 1,96$ dan probabilitas yang lebih kecil dari 0,05. Dengan demikian dapat disimpulkan bahwa hipotesis 1 (H1) menyatakan bahwa job satisfaction berpengaruh terhadap komitmen organisasional dan hipotesis diterima karena signifikan.

Berdasarkan standardized regession weight dapat diketahui bahwa indikator kepuasan dengan rekan sekerja merupakan indikator job satisfaction yang paling mengindikasikan peranan terbesar dalam mengukur job satisfaction, dengan nilai estimasi sebesar 0,822 , sedangkan indikator yang memiliki nilai indikator yang paling rendah adalah kepuasan terhadap pekerjaan itu sendiri sebesar 0,256. Hal tersebut menunjukkan bahwa kepuasan karyawan dengan teman sekerja mempengaruhi komitmen mereka terhadap perusahaan. Selain itu, kepuasan terhadap pekerjaan itu sendiri juga memberikan pengaruh terhadap komitmen walaupun kecil.

2. $\mathrm{H}_{2}$ : Pay satisfaction berpengaruh terhadap komitmen organisasional karyawan Bale Group Kebumen.

Parameter estimasi untuk pengujian pengaruh pay satisfaction terhadap komitmen organisasional menunjukkan nilai CR sebesar -2,056 dan dengan probabilitas sebesar 0,040. Kedua nilai tersebut diperoleh memenuhi syarat untuk penerimaan $\mathrm{H} 2$ yaitu nilai CR sebesar negatif 2,056 yang lebih besar dari $\pm 1,96$ dan probabilitas yang lebih kecil dari 0,05. Dengan demikian dapat disimpulkan bahwa hipotesis 2 (H2) menyatakan bahwa pay satisfaction berpengaruh terhadap komitmen organisasional dan hipotesis diterima karena signifikan.

Berdasarkan standardized regession weight dapat diketahui bahwa indikator ekuitas disebabkan karena perasaan mengenai ekuitas (keadilan/kewajaran) dalam penghasilan seseorang merupakan indikator pay satisfaction yang paling mengindikasikan peranan terbesar dalam mengukur pay satisfaction, dengan nilai estimasi sebesar 0,687 , sedangkan indikator yang memiliki nilai indikator yang paling rendah adalah organizational support atau perhatian pihak organisasi atas penyesuaian gaji terhadap kebutuhan hidup sebesar 0,520. Hal tersebut menunjukkan bahwa gaji yang diterima karyawan di Bale Group Kebumen cukup dan sebanding dengan kerja keras yang dilakukan selama bekerja mempengaruhi komitmen mereka terhadap perusahaan, Selain itu kepuasan terhadap gaji yang karyawan terima sesuai dengan peraturan sistem penggajian yang baik dan adil memberikan pengaruh terhadap komitmen walaupun kecil.

3. $\mathrm{H}_{3}:$ Job satisfaction berpengaruh terhadap turnover intention karyawan Bale Group Kebumen.

Parameter estimasi untuk pengujian pengaruh job satisfaction terhadap turnover intention menunjukkan nilai CR sebesar 2,097 dan dengan probabilitas sebesar 0,036. Kedua nilai tersebut diperoleh memenuhi syarat untuk penerimaan $\mathrm{H} 3$ yaitu nilai CR sebesar positif 2,097 yang lebih besar dari $\pm 1,96$ dan probabilitas yang lebih kecil dari 0,05. Dengan demikian dapat disimpulkan bahwa hipotesis $3(\mathrm{H} 3)$ menyatakan bahwa 
job satisfaction berpengaruh terhadap turnover intention dan hipotesis diterima karena signifikan.

Berdasarkan standardized regession weight dapat diketahui bahwa indikator kepuasan dengan rekan sekerja merupakan indikator job satisfaction yang paling mengindikasikan peranan terbesar dalam mengukur job satisfaction, dengan nilai estimasi sebesar 0,822 , sedangkan indikator yang memiliki nilai indikator yang paling rendah adalah kepuasan terhadap pekerjaan itu sendiri sebesar 0,256. Hal tersebut menunjukkan bahwa kepuasan karyawan dengan teman sekerja menurunkan tingkat turnover intention terhadap perusahaan. Selain itu, kepuasan terhadap pekerjaan itu sendiri juga menurunkan tingkat turnover intention terhadap perusahaan walaupun kecil.

4. $\mathrm{H}_{4}$ : Pay satisfaction berpengaruh terhadap turnover intention karyawan Bale Group Kebumen.

Parameter estimasi untuk pengujian pengaruh pay satisfaction terhadap turnover intention menunjukkan nilai CR sebesar 2,984 dan dengan probabilitas sebesar 0,003. Kedua nilai tersebut diperoleh memenuhi syarat untuk penerimaan $\mathrm{H} 4$ yaitu nilai CR sebesar positif 2,984 yang lebih besar dari $\pm 1,96$ dan probabilitas yang lebih kecil dari 0,05 . Dengan demikian dapat disimpulkan bahwa hipotesis 4 (H4) menyatakan bahwa pay satisfaction berpengaruh terhadap turnover intention dan hipotesis diterima karena signifikan.

Berdasarkan standardized regession weight dapat diketahui bahwa indikator ekuitas disebabkan karena perasaan mengenai ekuitas (keadilan/kewajaran) dalam penghasilan seseorang merupakan indikator pay satisfaction yang paling mengindikasikan peranan terbesar dalam mengukur pay satisfaction, dengan nilai estimasi sebesar 0,687 , sedangkan indikator yang memiliki nilai indikator yang paling rendah adalah organizational support atau perhatian pihak organisasi atas penyesuaian gaji terhadap kebutuhan hidup sebesar 0,520. Hal tersebut menunjukkan bahwa gaji yang diterima karyawan di Bale Group Kebumen cukup dan sebanding dengan kerja keras yang dilakukan selama bekerja menurunkan tingkat turnover intention terhadap perusahaan, Selain itu kepuasan terhadap gaji yang karyawan terima sesuai dengan peraturan sistem penggajian yang baik dan adil juga menurunkan tingkat turnover intention terhadap perusahaan walaupun kecil.

5. $\mathrm{H}_{5}$ : Komitmen organisasional berpengaruh terhadap turnover intention karyawan Bale Group Kebumen.

Parameter estimasi untuk pengujian pengaruh komitmen organisasional terhadap turnover intention menunjukkan nilai $\mathrm{CR}$ sebesar 1,103 dan dengan probabilitas sebesar 0,270. Kedua nilai tersebut diperoleh tidak memenuhi syarat untuk penerimaan $\mathrm{H} 5$ yaitu nilai CR sebesar positif 1,103 yang lebih kecil dari $\pm 1,96$ dan probabilitas yang lebih besar dari 0,05. Dengan demikian dapat disimpulkan bahwa hipotesis 5 (H5) menyatakan bahwa komitmen organisasional tidak berpengaruh terhadap turnover intention dan hipotesis ditolak karena tidak signifikan.

Berdasarkan standardized regession weight dapat diketahui bahwa indikator keterlibatan merupakan indikator komitmen organisasional yang paling mengindikasikan peranan terbesar dalam mengukur komitmen organisasional, dengan nilai estimasi sebesar 0,803 , sedangkan indikator yang memiliki nilai indikator yang 
paling rendah adalah identifikasi sebesar 0,545. Hal tersebut menunjukkan bahwa status karyawan dengan umur diantara 18-30 tahun mempunyai komitmen terhadap perusahaan yang rendah karena karyawan dengan umur 18-21 tahun masih sangat aktif mencari peluang pekerjaan di perusahaan lain yang lebih bagus, sehingga meningkatkan turnover intention. Namun disisi lain, karyawan dengan umur diantara 41-50 tahun memiliki komitmen yang tinggi terhadap perusahaan karena mereka sudah tidak dalam masa produktif untuk mencari pekerjaan di perusahaan lain yang lebih bagus sehingga hasil dari penelitian ini masih menunjukkan arah yang positif tapi tidak signifikan.

6. Berdasarkan hasil perhitungan pengaruh langsung maupun pengaruh tidak langsung job satisfaction dan pay satisfaction terhadap turnover intention karyawan, yang menunjukkan satu komparasi yang mengarah pada lebih tingginya pengaruh langsung dari pay satisfaction daripada job satisfaction terhadap turnover intention karyawan, dimana pengaruh pay satisfaction terhadap turnover intention karyawan secara langsung diperoleh sebesar 0,456 sedangkan secara tidak langsung diperoleh sebesar -0,050. Artinya pay satisfaction akan lebih bagus menurunkan tingkat turnover intention karyawan secara langsung meski tanpa didukung adanya komitmen organisasional yang tinggi. Begitu pula dengan job satisfaction yang menunjukkan bahwa pengaruh langsung lebih tinggi, diperoleh pengaruh job satisfaction terhadap turnover intention karyawan secara langsung diperoleh sebesar 0,299 sedangkan secara tidak langsung diperoleh sebesar 0,058 , artinya job satisfaction akan menurunkan tingkat turnover intention karyawannya lebih tinggi meski tidak dimediasi oleh komitmen organisasional.

\section{Kesimpulan}

1. Pengujian hipotesis yang dilakukan membuktikan bahwa ada pengaruh job satisfaction terhadap komitmen organisasional. Hal ini mendukung penelitian yang dilakukan oleh Agus Supriyadi (2013). Variabel job satisfaction menunjukkan berpengaruh terhadap komitmen organisasional, yang ditunjukkan dengan nilai signifikansi $<0,05$ yaitu sebesar 0,035, maka hipotesis 1 diterima.

2. Pengujian hipotesis yang dilakukan membuktikan bahwa ada pengaruh pay satisfaction terhadap komitmen organisasional. Hal ini mendukung penelitian yang dilakukan oleh R.M Ardian Avrianto Handoyo (2004). Variabel pay satisfaction menunjukkan berpengaruh terhadap komitmen organisasional, yang ditunjukkan dengan nilai signifikansi $<0,05$ yaitu sebesar 0,040, maka hipotesis 2 diterima.

3. Pengujian hipotesis yang dilakukan membuktikan bahwa ada pengaruh job satisfaction terhadap turnover intention. Akan tetapi, hal ini tidak mendukung penelitian yang dilakukan oleh Lia Witasari (2009). Variabel job satisfaction menunjukkan pengaruh terhadap turnover intention, yang ditunjukkan dengan nilai signifikansi $<0,05$ yaitu sebesar 0,036, maka hipotesis 3 diterima.

4. Pengujian hipotesis yang dilakukan membuktikan bahwa ada pengaruh pay satisfaction terhadap turnover intention. Akan tetapi, hal ini tidak mendukung penelitian yang dilakukan oleh Rita Andini (2006). Variabel pay satisfaction menunjukkan pengaruh terhadap turnover intention, yang ditunjukkan dengan nilai signifikansi $<0,05$ yaitu sebesar 0,003, maka hipotesis 4 diterima.

5. Pengujian hipotesis yang dilakukan membuktikan bahwa tidak ada pengaruh komitmen organisasional terhadap turnover intention. Akan tetapi Hal ini tidak mendukung penelitian yang dilakukan oleh Rita Andini (2006). Variabel komitmen organisasional 
menunjukkan pengaruh terhadap turnover intention, yang ditunjukkan dengan nilai signifikansi $>0,05$ yaitu sebesar 0,270 , maka hipotesis 5 ditolak.

\section{Saran}

Berdasarkan analisa dan kesimpulan yang telah dikemukakan di atas, maka saran yang dapat dikemukakan di sini adalah sebagai berikut:

Setelah melakukan analisis statistika terhadap jawaban responden mengenai indikator-indikator variabel penelitian dan menguji hipotesis maka dapat dihasilkan beberapa saran untuk manajemen Bale Group Kebumen berkaitan dengan penurunan tingkat turnover intention karyawan Bale Group Kebumen, yaitu :

1. Untuk menurunkan tingkat turnover intention karyawan Bale Group Kebumen, dilakukan dengan pendekatan terhadap variabel job satisfaction yang diupayakan dengan:

a. Memberikan kesempatan kepada karyawan untuk meningkatkan keterampilan misalnya kursus memasak bagi cook helper dan lain-lain.

b. Memberikan dukungan yang dilakukan oleh penyelia dalam bentuk bimbingan/bantuan teknik di lapangan maupun dukungan perilaku.

c. Meningkatkan solidaritas dan kerja sama dengan rekan kerja dalam hal pekerjaan.

2. Untuk menurunkan tingkat turnover intention karyawan Bale Group Kebumen, dilakukan dengan pendekatan terhadap variabel pay satisfaction yang diupayakan dengan:

a. Meningkatan nilai gaji dan memberikan tunjangan yang sesuai dengan kontribusi yang telah diberikan karyawan.

b. Memberikan insentif jika tingkat pengunjung memenuhi target tertentu.

c. Dalam melakukan sistem penggajian, hendaknya dilakukan secara adil, maksudnya yaitu gaji yang dibayarkan sesuai dengan kompetensi, keahlian dan pekerjaan (Internally Equitable) dan mempunyai nilai kompetitif di pasar (Externally Equitable).

3. Untuk menurunkan tingkat turnover intention karyawan Bale Group Kebumen, dilakukan dengan pendekatan terhadap variabel komitmen organisasional yang diupayakan dengan:

a. Mengadakan sosialisasi lebih mendalam tentang profil kafe dan resto dan peraturannya, baik peraturan langsung dari pemerintah maupun peraturan dalam perusahaan, misalnya hak dan kewajiban sebagai karyawan.

b. Melibatkan karyawan dalam setiap kegiatan organisasi, baik kegiatan di dalam maupun di luar organisasi, misalnya ulang tahun Bale Group Kebumen dan kegiatan keagamaan.

c. Membuka wadah khusus bagi karyawan untuk berinteraksi antar sesama karyawan sehingga mampu menjembatani level top manajemen dengan karyawan biasa agar terbina suatu hubungan yang kuat antara pimpinan dengan karyawan.

d. Memberikan reward kepada karyawan berprestasi dan keluarganya, seperti kenaikan jabatan dan gaji, gelar-gelar khusus sesuai bidang pekerjaan yang dilakukan di Bale Group Kebumen.

\section{Keterbatasan penelitian}

Adapun keterbatasan yang ditemukan dalam penelitian ini adalah nilai goodness of fit yang berada dalam kategori kurang baik. Untuk meningkatkan nilai goodness of fit yang baik maka pada agenda penelitian mendatang perlu mengkomposit indikator-indikator yang digunakan untuk mengukur variabel komitmen organisasional dan turnover intention. Hal ini demikian karena SEM dapat digunakan untuk menguji model yang kompleks namun apabila model terlalu kompleks dapat berdampak pada nilai goodness of fit yang poor. 


\section{DAFTAR PUSTAKA}

Abelson, M. A. 1987. Examination of Avoidable and Unavoidable Turnover. Journal of Applied Phsychology, 72: 382-386

Adams, J. 1965. Inequity in social exchange. In Advances in Experimental Social Psychology 2, edited by L. Berkowitz, 267-299. New York: Academic Press.

Andini, R. 2006. Analisis Pengaruh Kepuasan Gaji, Kepuasan Kerja, Komitmen Organisasional Terhadap Turnover Intention (Studi Kasus Pada Rumah Sakit Roemani Muhammadiyah Semarang). Tesis Magister Manajemen (Tidak dipublikasikan). Semarang: Program Pasca Sarjana Universitas Diponegoro.

Anwar Prabu. 1993. Psikologi Perusahaan. Bandung: Trigenda Karya.

Ari Kunto, Suharsimi, 2002. Prosedur Penelitian Suatu Pendekatan Praktek, Jakarta: Rineka Cipta.

As'ad, Mohammad, 1978. Psikologi Industri. Yogyakarta: Liberty.

Cherrington, D.J., 1994. Organization Behavior; The Management of Individual and Organizational Performance. New York: A Division of Simon of Schulter Inc.

Ferdinand, A. 2006. Structural Equation Modeling Dalam Penelitian Manajemen: Aplikasi Model-Model Rumit Dalam Penelitian Untuk Tesis Magister Dan Disertasi Doktor. Semarang: Penerbit Fakultas Ekonomi Universitas Diponegoro.

Ghozali, Imam. 2001. Aplikasi Analisis Multivariate Dengan Program Spss, Edisi Kedua. Semarang: Badan Penerbit Universitas Diponegoro.

. 2009. Aplikasi Analisis Multivariate Dengan Program Spss, Edisi Keempat. Semarang: Badan Penerbit Universitas Diponegoro.

Handoko, Hani. 1998. Manajemen Personalia dan Sumber Daya Manusia. Yogyakarta : BPFE.

Handoyo R.M. Ardian, A. 2004. Pengaruh Kepuasan kerja, Komitmen Organisasi Dan Kepuasan Gaji Terhadap Turnover Intention (Studi Empiris Pada Kantor Akuntan Publik di Semarang). Skripsi Sarjana (Tidak dipublikasikan). Semarang: Fakultas Ekonomi Universitas Katolik Soegijapranata.

Hasibuan, Malayu S.P. 2002. Manajemen Sumber Daya Manusia. Jakarta : Bumi Aksara. , 2009. Manajemen Sumber Daya Manusia, cetakan ketujuh Jakarta: Bumi Aksara.

Heneman, Schwab. 1986. Personnel/Human Resource Management ( $3^{\text {rd }}$ ed). Richard D. Irwin, Inc. 
Hersusdadikawati, E. 2005. Pengaruh Kepuasan Atas Gaji Terhadap Keinginan Untuk Berpindah Kerja Dengan Komitmen Organisasional Sebagai Variabel Intervening (Studi Empiris pada Dosen Akuntansi- Perguruan Tinggi Swasta Jawa Tengah). Tesis Magister Manajemen (Tidak dipublikasikan). Semarang: Program Pasca Sarjana Universitas Diponegoro.

Kreitner, Robert \& Angelo Kinicki, 2003, Perilaku Organisasi, Edisi kelima, Jakarta : Salemba empat.

, 2005. Perilaku Organisasi. Jakarta : Salemba empat.

Lee, T.W dan Mowday, R.T, 1987. "Voluntary Leaving an Organization : An Empirical Investigation of The Steers and Mowday 1981 Model of Turnover". Academy of Management Journal. Vol. 30. 721-743.

Lum, Lille, John Kervin, Kathleen Clark, Frank Reid \& Wendy Sola. 1999. Explaining Nursing Turnover Intent : Job Satisfaction, Pay Satisfaction, or Organizational Commitment. Journal of Organizational Behavior. Vol. 19, 305-320

Luthans, Fred. 1995. Organizational Behavior, McGraw Hill International, New York. . 2006. Perilaku Organisasi, Alih Bahasa V.A Yuwono. Yogyakarta : Andi.

Meyer, J.P, Allen N.J., and Smith C.A 1993. Commitment Organizational and Occupations: Extension and Tes of Three Component Conceptualization. Journal of Applied Psychology. 78:538-551.

Shaw, D, Jason, John E. Delery, G. Douglas J, Gupta, Nina, 1998. "An organizational Level Analysis of Voluntary and Involuntary Turnover". Academy of Management Journal. Vol. 41, No.5. 511-525.

Setiaji, Bambang. 2006. Panduan Riset dengan Pendekatan Kuantitatif. Surakarta: Muhammadiyah University Press.

Siagian Dan Sugiarto, 2006. Teori Pengembangan Organisasi, Jakarta: Bumi Aksara, Sinar Grafika Offset.

Sopiah. 2008. Perilaku Organisasi, Yogyakarta : Andi

Stephen P. Robbins, 1996, Perilaku Organisasi, Jilid 1 dan 2, Edisi Bahasa Indonesia, Perpustakaan Nasional. ,2001, Perilaku Organisasi, Jilid 1 Edisi 8, Jakarta : Prenhalindo , 2006, Perilaku Organisasi, Jakarta : Indek

Steers, R.M. 1988. Introduction to Organizational Behavior $\left(3^{\text {rd }}\right.$ ed $)$. Scott, Foresman Company. 
Sugiyono. 2004. Metode Penelitian Bisnis. Bandung: Alfabeta.

.2005. Memahami Penelitian Kualitatif. Bandung: Alfabeta.

. 2008. Memahami Penelitian Kualitatif. Bandung: Alfabeta.

.2010. Metode Penelitian Kuantitatif Kualitatif dan R\&D. Bandung: Alfabeta.

2012. Memahami Penelitian Kualitatif. Bandung : Alfabeta.

Supriyadi, A. 2013. Pengaruh Job Satisfaction Dan Pay Satisfaction Terhadap Komitmen Organisasi Karyawan Dan Turnover Intentions Di Mataram Sakti Kebumen. Skripsi Sarjana (Tidak dipublikasikan). Kebumen: STIE Putra Bangsa.

Sutrisno Hadi. 2004. Metodologi Riset. Jilid 3. Yogyakarta: Andi Offset.

Suwandi dan Nur Indriantoro. 1999. "Pengujian Model Turnover Pasewark dan Strawser : Studi Empiris pada Lingkungan Akuntansi Publik”. Jurnal Riset Akuntansi Indonesia, 2 : 173-195. Diambil dari http://jurnalakuntansi.petra.ac.id.

Timothy David Ryan, Michael Sagas, (2009) "Relationships between pay satisfaction, workfamily conflict, and coaching turnover intentions", Team Performance Management: An International Journal, Vol. 15 Iss: 3/4, pp.128 - 140. Diambil dari http://www.emeraldinsight.com.

Toly Agus, A. (2001). Analisis faktor-Faktor yang Mempengaruhi Turnover Intention pada Staf Kantor Akuntan Publik. Jurnal Akuntansi dan Keuangan : hal 102-125. Diambil dari http://jurnalakuntansi.petra.ac.id.

Witasari, L. 2009. Analisis Kepuasan Kerja Dan Komitmen Organisasional Terhadap Turnover Intentions (Studi Empiris pada Novotel Semarang). Tesis Magister Manajemen (Tidak dipublikasikan). Semarang: Program Pasca Sarjana Universitas Diponegoro.

Zeffane, Rachid, 1994, Understanding Employee Turnover : The Need for a Contingency Approach, International Journal of Manpower, Vol. 15, No. 9,pp. 114. 